\title{
İdare Hukuku Boyutuyla Ürün Yerleştirme
}

\section{Product Placement with Administrative Law Dimension}

\section{Muradiye Çevikçelik* (iD)}

\section{öz}

İzleyiciler reklam kuşağı başladığında genellikle kanalı değiştirmektedirler. Günün her anında yüzlerce reklama maruz kalan insanlar reklamların mesajları arasında farklılıkları algılayamamaktadırlar. Bu nedenle markalar mesajlarını iletebilmek için yeni mecralar aramaya yönelmişlerdir. Yenilikçi reklam stratejilerinden biri ürün yerleștirmedir. Ürün yerleştirme, bir markaya ait ürün veya hizmetin filmlere, televizyon veya radyo programlarına, kliplere, video oyunlarına, romanlara vb. dahil edilmesidir. $\mathrm{Bu}$ çalışmada öncelikle ürün yerleştirme kavramı ve Türk hukukunda ürün yerleştirmenin gelişimi incelenecektir. Devamında ürün yerleştirme yapılırken dikkat edilmesi gereken usul ve esaslar Radyo Televizyon Üst Kurulu kararları sşı̆̆ında değerlendirilecektir. Son olarak Kanun ve Yönetmelik’te öngörülen usul ve esaslara aykırılık halinde uygulanacak yaptırımlar ele alınacaktır.

Anahtar Kelimeler: Ürün Yerleştirme, Marka Yerleştirme, Gizli Ticari İletişim, Reklam, İdare Hukuku

\section{ABSTRACT}

When advertisements start, viewers generally change the channel. People, exposured to hundreds of advertisements at every moment of the day, cannot perceive differences between messages of advertisements. For these reasons, marketers have looked for a variety of new way to convey messages of brands. One of the innovative advertising stragies is product placement. Product placement is the integration of products and services in movies, television and radio programmes, clips, video games, novels etc. In this paper firstly concept and development of product placement in Turkish Law will be examined. Subsequently, procedures and principles to be considered during product placement will be examined in the light of decisions of the Radio and Television Supreme Council. Finally, sanctions to be applied in case of violation of procedures and principles stipulated in the Law and Regulation will be discussed.

Keywords: Product Placement, Brand Placement, Surreptitious Commercial Communication, Advertisement, Administrative Law

* Ar. Gör., Necmettin Erbakan Üniversitesi Hukuk Fakültesi İdare Hukuku Anabilim Dalı

Sorumlu Yazar/Correspondence Author: Muradiye Çevikçelik

E-posta/E-mail: mcevikcelik@erbakan.edu.tr

Geliş Tarihi/Received: $\quad$ 31.03.2021 Kabul Tarihi/Accepted: $\quad 25.04 .2021$ 


\section{GiRiş}

Avukat Steven L. Snyder makalesinde bir pazarlama sorumlusunun şu sözlerini aktarmaktadır: "Filmlerde hiçbir şey tesadüfi değildir. Filmde bir ürün kamerada görünüyorsa birinin o ürünü oraya koyduğundan emin olabilirsiniz"l. Gerçekten bir film veya televizyon programı izlerken başrol oyuncusu genellikle logosu gözüken giysiler ve aksesuarlar kullanmakta ve son model arabasina binmektedir. Bir yarışma programında kazanan yarışmacılar stüdyoda market adını verdikleri bölüme gitmekte ve markası gözüken ürünler arasından seçim yapmaktadır. Keza bir romanda karakterin kullandığg araç modeli uzun uzun betimlenmektedir.

Uygulamada ürün yerleştirmeye çeşitli şekillerde rastlamak mümkündür. Dolayısıla ürün yerleştirmeye dair doktrin ve uygulamada üzerinden uzlaşılmış bir tanım ve tasnif bulunmamaktadır. Ürün yerleştirmeye yer verilen yayında yalnızca ürün görseline yer verilebilmekte (görsel ürün yerleştirme) veya ürünün ismi yalnızca program içerisinde diyaloglarda zikredilmekle yetinilebilmektedir (işitsel ürün yerleştirme). Bir diğer ihtimalde ise hem ürün görseline yer verilmekte hem de ürün program içerisinde zikredilmektedir (görsel ve işitsel ürün yerleştirme). Ürün yerleştirmeye konu olan bazı ürünler karakterler tarafından kullanılabilmekte (aktif ürün yerleştirme), bazı ürünlerse kurguyla herhangi bir ilgisi olmadan sadece ekranda gözükmektedir (pasif ürün yerleştirme)2.

Türk hukukunda 2011 yılına kadar ürün yerleştirme örtülü reklam yasağının ihlali olarak değerlendirilmiştir. 2011 yılında ise 6112 sayılı Radyo ve Televizyonların Kuruluş ve Yayın Hizmetleri Hakkında Kanun (Kanun) ${ }^{3}$ ile belirli programlarda belirli şartlar altında ürün yerleştirmeye yer verilebileceği kabul edilmiştir. Böylece bu tarihe kadar sıklıkla başvurulan ürün yerleştirme uygulaması yasal dayanağa kavuşmuştur. Bu çalışmada öncelikle Türk hukukunda yayın hizmetlerinin hukuki niteliği incelenecektir. Devamında ise ürün yerleştirme kavramı ve Türk hukukundaki yeri Radyo Televizyon Üst Kurulu (RTÜK) kararları ışı̆̆ında ele alınacaktır.

\section{TÜRK HUKUKUNDA YAYIN HIZMETLERININ HUKUKI NITELIĞi}

6112 sayılı Kanun'un 3/1-ff bendine göre yayın hizmetleri "Medya hizmet sağlayıcının editoryal sorumluluğu altında ve temel amacı kamuoyunu bilgilendirmek, eğlendirmek veya eğitmek üzere elektronik iletişim şebekeleri yoluyla program sunmak olan, bireysel iletişim hariç olmak üzere, televizyon yayın hizmeti, isteğe bağl yayın hizmeti ve ticarî iletişim ile radyo yayın hizmetini” ifade etmektedir. Yayın hizmetleri toplumu bilgilendirmek, eğlendirmek, eğitmek ve haberleşmeyi sağlamak amacıyla

1 Arşivlerde yaptığımız araştırmalarda Snyder'in atıf yaptığı Adweek dergisinin 3 Nisan 1989 sayısına ve dolayısıyla bu sözlerin sahibine ulaşamadık. Aktaran SNYDER Steven L, "Movies and Product Placement: Is Hollywood Turning Films into Commercial Speech”, University of Illinois Law Review, C. 1992, S. 1, 1992, s. 301.

2 Ürün yerleştirmenin tasnifi ayrı bir çalışmanın konusunu oluşturacak niteliktedir. Ayrıntılı bilgi için bkz. ZEREN Deniz/ PAYLAR Önder Ziya, Ürün Yerleştirme, Karahan Kitabevi, Adana, Kasım 2014, s. 18-21; YOLCU Tarık, Pazarlama İletişim Aracı Olarak Film ve Dizilerde Ürün Yerleştirme, İKSAD Yayınevi, Ankara, 2020, s. 83-99.

RG: 03.03.2011/27863. 
yerine getirilen kamu hizmeti niteliğinde faaliyetlerdir ${ }^{4}$. Ülkemizde radyo ve televizyon yayıncılığı faaliyetleri uzun yıllar devlet eliyle yürütülmüştür ${ }^{5}$. 1961 Anayasası'nın 121. maddesinde ${ }^{6}$ ve 1982 Anayasası'nın 133. maddesinin ilk halinde ${ }^{7}$ radyo ve televizyon yayıncılı̆̆ı hizmetlerini sunmak devletin tekeline bırakılmıştır. Ancak 08.07.1993 tarihinde kabul edilen 3913 sayılı Kanun ${ }^{8}$ ile yayın hizmetlerinin sunulmasında yeni bir döneme geçilmiş ve özel radyo ve televizyon kuruluşları hizmet vermeye başlamıştır 9 .

3913 sayılı Kanun her ne kadar devletin yayın hizmetleri alanındaki tekel konumunu kaldırsa da yayın hizmetlerinin hukuki statüsünde herhangi bir değişikliğe yol açmamıştır. Zira özel radyo ve televizyon kuruluşları tarafından verilen yayın hizmetleri de toplumu eğlendirmesi, eğitmesi, toplumun haber alma ihtiyacını karşılaması gibi yönlerden kamu yararının gerçekleşmesine hizmet etmektedir. Özel radyo ve televizyon kanalları her bir yayın tekniği ve ortamına ilişkin RTÜK’ten ayrı ayrı lisans almaları kaydıyla yayıncılık faaliyetlerinde bulunabilmektedirler (6112 sayılı Kanun m. 27/1). RTÜK’ten lisans alan özel radyo ve televizyon kuruluşları tarafından yayıncılık faaliyetlerinin 6112 sayılı Kanun'da öngörülen usul ve esaslara uygun olarak yerine getirilmesi gerekmektedir. Dolayısıyla günümüzde gerek devlet gerekse özel kuruluşlar tarafından sunulan yayın hizmetlerinin kamu hizmeti niteliği taşıdığı kabul edilmektedir ${ }^{10}$. Ancak özel radyo ve televizyon kuruluşları tarafından yerine getirilen yayıncılık faaliyetlerinin kamu yararına sonuçlar doğurması bu kuruluşların öncelikli amaçlarının kâr elde etme olduğu gerçeğini değiştirmemektedir. Bu nedenle özel radyo ve televizyon kuruluşları tarafından yerine getirilen faaliyetin virtüel kamu hizmeti niteliğinde olduğu ifade edilmektedir.

İlk defa Fransa’da ortaya çıkan virtüel kamu hizmeti kavramı organik anlamda kamu hizmeti olmayan ancak fonksiyonel anlamda kamu hizmeti niteliği taşıyan, kamusal bir ihtiyacın tatminine yönelen ve özel kişilere idare tarafından verilen ruhsat ile yerine getirilen faaliyetleri ifade etmektedir ${ }^{11}$. İdare,

4 Anayasa Mahkemesine göre radyo ve televizyon yayını çağın en ileri teknolojik aşamasına ulaşmış bir kamu hizmetidir ve Anayasa’da öngörülen nitelikleri taşımalıdır. AYM, T. 18.05.1990, E. 1989/9, K. 1990/8, RG: 26.07.1990/20586.

5 İSBİR Begüm, "Kamu Hizmeti İlkeleri Işığında Özel Radyo-Televizyon Yayıncılığının Değerlendirilmesi”, Gazi Üniversitesi Hukuk Fakültesi Dergisi, C. 21, S. 1-2, 2007, s. 818.

61961 Anayasası’nın 121. maddesinin 1. fikrasının ilk hâli "Radyo ve televizyon istasyonlarının idaresi, özerk kamu tüzel kişiliği halinde, kanunla düzenlenir." şeklindedir. 1971 yllında Anayasa değişikliğiyle söz konusu hüküm "Radyo ve televizyon istasyonlar, ancak Devlet eliyle kurulur ve idareleri tarafsız idaresi ve bir kamu tüzel kişiliği halinde kanunla düzenlenir, Kanun, yönetim ve denetimde ve yönetim organlarının kuruluşunda tarafsılık ilkesini bozacak hükümler koyamaz." şeklinde değiştirilmiştir. RG: 22.09.1971/13964.

71982 Anayasası'nın 133. maddesinin 1. fikrasının ilk hâli "Radyo ve televizyon istasyonları, ancak Devlet eli ile kurulur ve idareleri tarafsız bir kamu tüzelkişiliği halinde düzenlenir." şeklindedir.

82709 Sayılı Türkiye Cumhuriyeti Anayasasının 133 üncü Maddesinin Değiştirilmesi ile İlgili Kanun, RG: 10.07.1993/21633.

91982 Anayasası’nın 133. maddesinin ilk fıkrasının son hâli "Radyo ve televizyon istasyonları kurmak ve işletmek kanunla düzenlenecek şartlar çerçevesinde serbesttir.” şeklindedir.

10 Aynı yönde bkz. AYAYDIN Dilhun, Radyo ve Televizyon Üst Kurulu’nun Kamu Yayıncılığı ve Özel Yayıncılık Üzerindeki Yetkileri (Yayımlanmamıș Doktora Tezi), Ankara Üniversitesi, Sosyal Bilimler Enstitüsü, Ankara, 2014, s. 354-355; İSBİR, s. 826.

11 AKYILMAZ Bahtiyar/SEZGİNER Murat/KAYA Cemil, Türk İdare Hukuku, 10. Baskı, Savaş Yayınevi, Ankara, 2019 , s. 566; GÜLAN Aydın, “Kamu Hizmeti Kavramı”, İdare Hukuku ve İlimleri Dergisi, C. 9, S. 1-3, 1988, s. 156-159; YAŞAR Nuri, "Kamu Hizmeti, Virtüel Kamu Hizmeti ve 1999 Anayasa Değişikliği”, İdare Hukuku ve İlimleri Dergisi, C. 14, S. 1, 2000, s. 406-407; Virtüel kamu hizmeti teorisine ilişkin eleştiriler için bkz. GÖZLER Kemal/KAPLAN Gürsel, 
özel kişilerin yerine getirdiği virtüel kamu hizmeti sayılan faaliyetler üzerinde klasik kolluk denetimini aşan hiyerarşiye yaklaşan bir içerik denetimi yapmakta ${ }^{12}$ ve yürütülen faaliyetin muhtevasını düzenleyebilmektedir ${ }^{13}$. Yayıncılık hizmetlerinin virtüel kamu hizmeti teorisi kapsamında değerlendirilmesi mümkündür. Zira özel kuruluşların yayıncılık faaliyetlerinde bulunabilmesi için öncelikle RTÜK’ten yayın lisansı alması gerekmektedir. Özel radyo ve televizyon kanallarında yapılacak yayınların muhtevası, gözetilecek ilkeler ve uygulanacak yaptırımlar 6112 sayılı Kanun'da düzenlenmiştir. RTÜK’e verilen yetkiler, denetimin yanında yayın hizmetlerinin muhtevasının düzenlenmesini de içermektedir ${ }^{14}$. Dolayısıyla özel kuruluşlar tarafından gerçekleştirilen yayıncılık faaliyetlerinin salt ticari bir faaliyet olarak değerlendirilmesi mümkün değildir.

\section{II. ÜRÜN YERLEŞTIRME KAVRAMI}

Kurum ve kuruluşlar ürettikleri ürünler için yeni pazarlar bulmak, mevcut pazarlarını genişletmek, kâr elde etmek veya marka tanınırlığını artırmak amacıyla reklamlara başvurmaktadırlar ${ }^{15}$. 6112 sayılı Kanun'a göre radyo ve televizyon reklamı, "taşınmazlar, hak ve yükümlülükler dâhil olmak üzere mal veya hizmetlerin teminini teşvik etmek, bir amaç veya düşünceyi yaymak veya başka etkileri oluşturmak amacıyla ticaret, iş, zanaat veya bir meslekle bağlantıl gerçek ve tüzel kişi tarafindan, bir ücret veya benzeri bir karşılıkla yapılan her türlü duyuru veya öz tanıtım yayınını" ifade etmektedir. Bir duyuru veya yayının reklam kabul edilebilmesi için bir mesajının bulunması, belirli bir vasıtanın kullanılması, reklam verenin belli olması, reklam yapma iradesinin varlığı ve reklamın ücret karşılığı yapılması unsurlarının mevcudiyeti aranmaktadır ${ }^{16}$.

Reklam başladığında izleyicilerin kanalı değiştirmeleri ${ }^{17}$ ve artan rekabet nedeniyle insanların adeta reklam ve markalarla kuşatılması ${ }^{18}$ geleneksel reklamların etkisini oldukça azaltmıştır. Günümüzde küreselleşmenin ve rekabetin etkisini artırması, teknolojide baş döndürücü gelişmelerin yaşanması, özellikle COVID-19 pandemisi sürecinde karantina ve sokağa çıkma yasakları sebebiyle cep telefonu

İdare Hukuku Dersleri, 22. Baskı, Ekin Kitabevi, Bursa, 2020, s. 497; SERTER Yusuf Sertaç, Kamu Hizmeti Kavramının Ekonomik Nedenlerle Geçirdiği Dönüşüm Bağlamında Virtüel Kamu Hizmeti ve Evrensel Hizmet Kurumları Üzerine Bir Karşılaştırma, Adalet Yayınevi, Ankara, 2019, s. 85-86.

12 ÖZAY İl Han, Günışı̆̆ında Yönetim, 3. Baskı, Filiz Kitabevi, İstanbul, 2017, s. 226.

13 AKYILMAZ/SEZGINER/KAYA, s. 566.

14 İSBİR, s. 829.

15 YILDIRIM Erhan/CAN Aytekin, "Reklamcılığın Farklı Bir Yüzü Olan Ürün Yerleştirmenin Televizyon Dizilerinde Kullanımı ve And Pastel İnşaatın ‘İstanbul'lu Gelin’ Dizisi İçerisinde Ürün Yerleştirme Uygulamasının Çözümlemesi”, Selçuk İletişim, C. 12, S. 2, 2019, s. 683; SÜRÜCÜ Pelin, "Marka Yerleştirmenin Bir Reklam Olarak Etkileri: Video Oyunlarındaki Marka Yerleştirme Uygulamaları Üzerine Keşifsel Bir Araştırma”, Hacettepe Üniversitesi İktisadi ve İdari Bilimler Fakültesi Dergisi, C. 25, S. 2, 2007, s. 176.

16 ALTUN Abdurrahim, Türk Borçlar Hukukunda Reklam Yapım Sözleşmesi, Adalet Yayınevi, Ankara, Ocak 2020, s. 2631.

17 YILDIRIM/CAN, s. 683; SÜRÜCÜ’nün ifadesiyle günümüzde reklam kuşakları "film ya da dizi başlamadan önce bitirilecek işlerin yapılacağı zaman kuşăğ ” şeklinde anlaşılmaktadır. SÜRÜCÜ, s. 177.

18 MAZICI Emel Tanyeri/ATEŞ Nur Banu/YILDIRIM Ayşe, “Televizyon Programlarında Ürün Yerleştirme: "Survivor All Star” Örneği”", Selçuk İletişim, C. 9, S. 4, 2017, s. 239. 
kullanımında yaşanan $\operatorname{artış~}{ }^{19}$ ve insanların adeta reklam bombardımanına maruz kalması geleneksel reklam stratejilerinin zayıflamasına ve markaların dikkat çekmek amacıyla daha yenilikçi reklam stratejileri oluşturmaya çalışmalarına yol açmışıır²0

Kurum ve kuruluşlar tarafından izleyicilerin dikkatini çekmek amacıyla başvurulan yenilikçi reklam stratejilerinden biri ürün yerleştirmedir. 6112 sayılı Kanuna göre ürün yerleştirme "bir ürün, hizmet veya ticarî markanın, ücret veya benzeri bir karşllkla program içine dâhil edilerek veya bunlara atıf yapılarak, program içinde gösterildiği her tür ticarî iletişimi" (m. 3/1-cc), ticari iletişim ise "radyo ve televizyon reklamları, program desteklemesi, tele-alş̧veriş ve ürün yerleştirmeyi de kapsamak üzere, ekonomik bir faaliyette bulunan gerçek veya tüzel kişsinin, ürün, hizmet veya imajını, doğrudan veya dolayl olarak tanıtmak amacıyla tasarlanmış sesli veya sessiz görüntülerin bir ücret veya benzeri bir karşıllkla ya da öz tanıtım amacıyla bir programla birlikte ya da bir program içine yerleștirilerek verilmesini" (m. 3/1-z) ifade etmektedir.

Ürün yerleştirme, reklamı yapılmak istenen bir ürün veya markanın mesajının filmlere, televizyon ve radyo programlarına, video ve bilgisayar oyunlarına, romanlara veya kliplere planlı ve göze batmayacak şekilde ${ }^{21}$ dahil ederek izleyicileri etkilemeyi amaçlayan bir reklam türüdür ${ }^{22}$. ER'in de ifade ettiği gibi, ürün yerleştirme uygulamasıyla insanlar film, televizyon programı veya tiyatro oyunu izlerken, radyo programı dinlerken veya roman okurken savunmasız olduğu anlarda yakalanmakta ve mesajdan kaçamamaktadır ${ }^{23}$. Ürün yerleştirme uygulamasında izleyiciler kanal değiştirememekte ve reklamı izlemeye mecbur kalmakta, ürün yerleştirme yapılan programların yurt dışında gösteriminin yapılması mesajın daha geniş kitlelere ulaştırılmasını sağlamakta ${ }^{24}$ ve tekrar tekrar izlenen programlarda aynı reklam defalarca insanların karşısına çımaktadır ${ }^{25}$. Ürün yerleştirmeyle mal veya hizmet satışını artırarak kâr elde etmenin ötesinde marka tanınırlığını artırmak amaçlanmaktadır. Doktrinde ürün yerleştirme yerine marka yerleştirme kavramının kullanıldığı veya marka yerleştirmenin ürün yerleştirmeden bağımsız olarak ele alındığ 1 çalışmalara rastlamak mümkündür. Marka tanınırlığı, markanın diğer markalar arasında ön plana çıkmasını ve satın alma kararının söz konusu marka lehine yapılmasını sağlamaktadır ${ }^{26}$.

19 SYDOW Lexi, “The Impact of Coronavirus on the Mobile Economy”, https://www.appannie.com/en/insights/marketdata/coronavirus-impact-mobile-economy/, Erişim Tarihi: 12.03.2021.

20 GUPTA Pola B./BALASUBRAMANIAN Siva K./KLASSEN Michael L., "Viewers' Evaluations of Product Placements in Movies: Public Policy Issues and Managerial Implications”, Journal of Current Issues \& Research in Advertising, C. 22, S. 2, 2000, s. 42 .

21 BALASUBRAMANIAN Siva K., "Beyond Advertising and Publicity: Hybrid Messages and Public Policy Issues”, Journal of Advertising, C. 23 S. 4, 1994, s. 31.

22 ÖZTÜRK Selen/OKUMUŞ Abdullah, "Pazarlama İletişimi Aracı Olarak Ürün Yerleştirme: Kavramsal Bir Çerçeve”, İstanbul Üniversitesi İşletme Fakültesi İşletme İktisadı Enstitüsü Yönetim Dergisi, C. 25, S. 76, 2014, s. 2; YOLCU, s. 45; GUPTA Pola B./LORD Kenneth R., "Product Placement in Movies: The Effect of Prominence and Mode on Audience Recall”, Journal of Current Issues \& Research in Advertising, C. 20, S. 1, 1998, s. 47; AKTEKİN Uğur/GÜRBÜZ Bahar, “Türkiye’de Örtülü Reklamlar ve Uygulamadaki Durum”, Ankara Barosu Fikri Mülkiyet ve Rekabet Hukuku Dergisi, C. 9, S. 4, 2009, s. 49; ZEREN/PAYLAR, s.10; SNYDER, s. 301.

23 ER Eda, "Reklam ve Sinema: Sinema Filmlerinde Ürün Yerleştirme”, Yeni Düşünceler, S. 7, 2013, s. 146.

24 ER, s. 155.

25 SÜRÜCÜ, s. 176.

26 YILDIRIM/CAN, s. 692; YOLCU, s. 46-47; YAZICI Fikret, “Ürün Yerleştirme Uygulamasının Hukuki Boyutu: ABD, 
Ürün yerleştirmenin öne çıkan bir diğer yönü izleyicilerle ürün arasında duygusal bir bağ kurulmasını sağlamasıdır. Sevdiği bir filmi izleyen izleyici, kendisine yakın bulduğu karakterin bir mal veya hizmete dair mesajı vermesi üzerine söz konusu mal veya hizmetle ya da markayla duygusal bir ilişki kurmaktadır. Başarılı bir ürün yerleştirme uygulaması reklamı yapılan mal, hizmet veya marka ile programdaki karakterin imajının örtüşmesini ${ }^{27}$ ve özdeşleşmesini ${ }^{28}$ sağlamalıdır. Çoğu zaman ünlü kişilerin vücutları vitrin olarak kullanılmakta, çeşitli markaların giysi ve aksesuarları bu yolla sergilenmektedir ${ }^{29}$. Böylece tüketicinin satın alma tercihleri etkilenmekte ve markanın tanınırlığı artmaktadır. Bu yönü itibariyle ürün yerleştirme, klasik reklam kuşaklarına kıyasla daha doğal ve saldırgan olmayan bir yöntem olarak değerlendirilmektedir ${ }^{30}$. Hatta yapılan araştırmalara göre izleyiciler ürün yerleştirmeyi daha az yanıltıcı ve sempatik bulmaktadır ${ }^{31}$. Bu yönü itibariyle ürün yerleştirme uygulamasının etik boyutu doktrinde tartışmalara konu olmuştur. Korumacı görüşe göre reklam mesajlarına maruz kalan izleyiciler programın içeriğiyle reklam arasındaki farkı algılayamamaktadır. Böylece izleyiciler adeta kandırılmakta ve izleyicilerin duyguları istismar edilmektedir ${ }^{32}$. Aksi yönde görüşe göre ise günümüzde ürün yerleștirme yapılan yayınlarda reklamın nerede başladığı ve nerede bittiği açıkça anlaşılmaktadır. İzleyiciler profesyonel ve yaratıcı ürün yerleştirme uygulamaları sayesinde izledikleri veya dinledikleri reklamı yayından kolayca ayırt edebilmektedir ${ }^{33}$.

Ürün yerleştirme, oldukça büyük bütçeli dizi, film ve programların çekilebilmesi için finansal destek sağlaması, dizi ve filmlere gerçekçilik katması ve böylece bunları daha inandırıcı kılması yönleriyle yapımcılar tarafından savunulmaktadır ${ }^{34}$. Ürün yerleştirme, ürün veya hizmetin mesajının mükemmel bir şekilde izleyicilere verilerek markayı popülerleştirmeyi ve ölümsüz kılmayı sağladığı için piyasa tarafından desteklenmektedir. Ayrıca ürün yerleștirme yoluyla verilen mesaj uzun ömürlü olmaktadır ${ }^{35}$. Örneğin, ürün yerleștirme yapılan bir film sinema salonlarında, televizyonda ve hatta yurt dışında seyirciyle buluşabilmekte ve mesajını geniş kitlelere kolaylıkla ulaştırabilmektedir.

Ticari iletişim türlerinden biri olan ürün yerleştirme uygulaması ifade özgürlüğü ile sıkı bir ilişki içerisindedir. İfade özgürlüğü Avrupa İnsan Hakları Sözleşmesỉnin (AİHS) ${ }^{36}$ 10. maddesinde

Avrupa Ülkeleri ve Türkiye Üzerine Bir Değerlendirme”, Erciyes Üniversitesi Sosyal Bilimler Enstitüsü Dergisi, C. 30, S. 40, 2016, s. 94.

YOLCU, s. 50.

ZEREN/PAYLAR, s. 13.

ZEREN/PAYLAR, s. 18; Tom Cruise 1983 yapımı Risky Business filminde Ray-Ban markasının Wayfarer modelini ve 1986 yapımı Top Gun filminde aynı markanın Aviator modelini kullanmaktadır. Risky Business filminin afişinde de Tom Cruise Ray-Ban gözlügüüle yer almaktadır. Hatta afişte Risky Business ifadesi Ray-Ban logosunda kullanılan yazı stiliyle yazılmış ve tıpkı logodaki gibi eğimli şekilde afişe yerleştirilmiştir. Her iki ifade de kelimelerin " $R$ " ve " $B$ " ile başladığı da dikkat çekmektedir.

YILDIRIM/CAN, s. 689

SÜRÜCÜ, s. 185.

YAZICI, s. 98; YOLCU, s. 52; GUPTA/BALASUBRAMANIAN/KLASSEN, s. 44; ZEREN ve PAYLAR, s. 21.

TIĞLI Mehmet, "Bir Aktör Olarak Markalar: Ürün Yerleştirme", Türkmen Kitabevi, İstanbul, 2004, 41; YOLCU, s. 52.

SNYDER, s. 308-309; GUPTA/BALASUBRAMANIAN/KLASSEN, s. 43-44.

GUPTA/BALASUBRAMANIAN/KLASSEN, s. 42.

İnsan Haklarım ve Ana Hürriyetleri Koruma Sözleşmesi ve Buna Ek Protokolün Tasdiki Hakkında Kanun, Kanun No: 
düzenlenmiştir. Maddenin ilk fikrasına göre, "Herkes ifade özgürlüğü hakkına sahiptir. Bu hak, kamu makamlarının müdahalesi olmaksızın ve ülke sinırları gözetilmeksizin, kanaat özgürlüğünü ve haber ve görüş alma ve de verme özgürlüğünü de kapsar. Bu madde, Devletlerin radyo, televizyon ve sinema işletmelerini bir izin rejimine tabi tutmalarına engel değildir”. Maddenin ikici fikrasında ifade özgürlüğünün nasıl sınırlandırllabileceği düzenlenmektedir. AİHS’nin 10. maddesine paralel bir düzenleme 1982 Anayasası̉nın "Düşünceyi açıklama ve yayma hürriyeti” kenar başlıklı 26. maddesinde yer almaktadır. Maddenin ilk fikrasına göre, "Herkes, düşünce ve kanaatlerini söz, yazı, resim veya başka yollarla tek başına veya toplu olarak açıklama ve yayma hakkına sahiptir. Bu hürriyet Resmî makamların müdahalesi olmaksizın haber veya fikir almak ya da vermek serbestliğini de kapsar. Bu fikra hükmü, radyo, televizyon, sinema veya benzeri yollarla yapılan yayımlarm izin sistemine bağlanmasına engel değildir”. Maddenin ikinci fikrasında düşünceyi açıklama ve yayma hürriyetinin sınırlandırılmasına ilişkin hususlar düzenlenmiştir.

İfade özgürlüğü ile basın özgürlüğü arasında sıkı bir ilişki mevcuttur. İfade özgürlügünün olmadığı bir ortamda basın özgürlüğünden de söz edilemeyecektir. Basın özgürlüğü Anayasảnın 28. maddesinde güvence altına alınmıştır. 28. maddenin ilk fikrasına göre, "Basın hürdür, sansür edilemez. Basımevi kurmak izin alma ve mali teminat yatırma şartına bağlanamaz". 28. maddenin ikinci fikrasında devletin basın ve haber alma hürriyetlerini sağlayacak tedbirleri almakla yükümlü olduğu ifade edilmiştir. Maddenin diğer fikralarında basın özgürlüğünün sınırlandırılmasına ilişkin usul ve esaslar düzenlenmiştir.

Ürün yerleștirme uygulamalarının ifade özgürlüğü kapsamında değerlendirilip değerlendirilemeyeceği tartı̧̧maya açık bir husustur. Zira günümüzde genelde reklamların özelde ise ürün yerleştirme uygulamalarının çeşitli etik sorunlar doğurduğu kabul edilmektedir. Bu nedenle ulusal ve uluslararası mevzuatla, meslek kuruluşları ve basın örgütleri tarafından yapılan çalışmalarla reklamlara dair etik ilkeler ortaya konulmaktadır ${ }^{37}$. Ürün yerleştirme, Amerika Birleşik Devletleri’nde $(\mathrm{ABD})$ aksi yönde görüşler olsa da ifade özgürlüğü kapsamında anayasal bir hak olarak değerlendirilmekte; Avrupa Birliği ve Türkiyede ise ticari iletişim faaliyeti olarak kabul edilmekte ve korumacı yaklaşım ön plana çıkmaktadır ${ }^{38}$.

\section{TÜRK HUKUKUNDA ÜRÜN YERLEŞTIRME}

Türk hukukunda radyo ve televizyon yayın hizmetleri hususunda 6112 sayılı Kanun bir dönüm noktası niteliği taşımaktadır. 6112 sayılı Kanun, Avrupa Birliği Görsel-İşitsel Medya Hizmetleri Yönergesi (Audiovisual Media Services Directive) ${ }^{39}$ ile uyum sağlamak amacıyla kabul edilmiştir. Ürün yerleștirme uygulaması, 2011 yılında kabul edilen 6112 sayılı Kanun ile hukuki dayanağına kavuşmuştur. Ancak uygulamada bu tarihten önce de ürün yerleştirme yoluna başvurulduğu

6366, Kabul Tarihi: 10.03.1954, RG: 19.03.1954/8662.

37 ÇATALOĞLU Burcu Bahar, "Reklama Hukuki Açıdan Bir Bakış", Yıldırım Beyazıt Hukuk Dergisi, C. 5, S. 2, 2020, s. 619.

38 YAZICI, s. 116-117.

39 https://eur-lex.europa.eu/legal-content/EN/TXT/?uri=CELEX\%3A02010L0013.201.81218\#B-16, Erişim Tarihi: 14.03.2021. 
bilinmektedir. Ülkemizde ürün yerleştirme ve örtülü reklama ilişkin tartışmaların başlangıç noktası Mustafa Sandal’’n 1996 çıkışlı “Araba” isimli şarkısının klibi olmuştur ${ }^{40}$. Klipte trafikte yol alan bir kamyonetin üzerinde ve bir reklam panosunda alkollü bir içki markası yer almaktadır. Ürün yerleştirme tartışmaları 12 markanın yerleştirildiği 2004 yapımı G.O.R.A. filmiyle oldukça alevlenmiştir ${ }^{41}$. Bunun üzerine Reklam Kurulu (RK), G.O.R.A. filminde örtülü reklam yapıldı̆̆ından bahisle Beşiktaş Kültür Merkezi Ltd. Şti.'yi idari para cezası ile cezalandırmıştır ${ }^{42}$.

Ürün yerleştirme örtülü reklamın ${ }^{43}$ bir türü olarak kabul edilmektedir. Örtülü reklam, 6502 sayılı Tüketicinin Korunması Hakkında Kanun'un ${ }^{44}$ 61. maddesinin 4. fikrasında tanımlanmıştır. Bu hükme göre, "reklam olduğu açıkça belirtilmeksizin yazı, haber, yayın ve programlarda, mal veya hizmetlere ilişkin isim, marka, logo veya diğer ayırt edici şekil veya ifadelerle ticari unvan veya işletme adlarının reklam yapmak amacıyla yer alması ve tanıtıcı mahiyette sunulması örtülü reklam olarak kabul edilir”. Maddenin devamında ise her türlü iletişim aracında örtülü reklam yapılmasının yasak olduğu vurgulanmıştır.

Örtülü reklam, 6112 sayılı Kanun'un 3/1-g bendinde "gizli ticari iletişim” adı altında tanımlanmıştır. $\mathrm{Bu}$ tanıma göre gizli ticari iletişim, "medya hizmet sağlayıcı tarafından reklam yapmak maksadıyla veya kamuyu yönlendirebilecek şekilde; mal veya hizmet üreticisinin faaliyetinin, ticarî markasının, adının, hizmetinin ve ürününün reklam kuşakları dışında ve reklam yapıldığına ilişkin açıklayıcı bir ses veya görüntü bulunmaksızın programlarda sözcükler veya resimler ile tanıtılmasını" ifade etmektedir. Aynı tanım Yayın Hizmeti Usul ve Esasları Hakkında Yönetmelik’in (Yönetmelik) ${ }^{45}$ 4/1-ğ bendinde de yer almaktadır. 6112 sayılı Kanun'un 9. maddesinde ticari iletişimin yayın hizmetinden kolayca ayırt edilebilir nitelikte olması gerektiği ve gizli ticari iletişime izin verilmeyeceği düzenlenmiştir.

Örtülü reklam, ulusal düzenlemelerin yanı sıra uluslararası düzenlemelerle de yasaklanmıştır. Avrupa Birliği Görsel-İşitsel Medya Hizmetleri Yönergesi’nin 9. maddesi uyarınca gizli görsel-işitsel ticari iletişim yasaklanacaktır. Ülkemizin de taraf olduğu Avrupa Sınırötesi Televizyon Sözleşmesi’nin ${ }^{46}$ 13. maddesinin 1. fikrasında reklamların programlardan kolaylıkla ayırt edilebilecek nitelikte

40 TÜZÜN ATEŞALP Selin/TAŞDEMİR Babacan, "Ürün Yerleştirme ve Editoryal İçerik ile İlgili Artan Kaygılar: Türkiye'de Televizyon Draması Sektörü Örneği”, Galatasaray Üniversitesi İletişim Dergisi, S. 21, 2014, s. 58.

41 YAZICI, s. 107; TÜZÜN ATEŞALP/TAŞDEMİR, s. 58.

42 Reklam Kurulu, 2005/48 nolu karar, 12.04.2005 tarih ve 115 sayılı toplantı, http://www.ssuk.org.tr/eski_site_verileri/ kurul/115.doc, Erişim Tarihi: 23.03.2021.

43 “...adresli internet sitesinde yaymlanan “Tretin Krem Nedir, Ne İşe Yarar, Tretin Krem Kullananların Yorumları” başlıklı yazı içerisinde, "Tretin” adlı ürüne ilişkin ürün özellikleri, cilt sağh̆ğı üzerindeki etkileri hakkında, tüketicilerin aydınlanma, bilgilendirilme ihtiyacını karşılama ve haber verme amacının dışına çıkan ifadelerin kullanıldığı; bununla birlikte, bahsi geçen ürünün fotoğrafi, fiyatı ve nasıl temin edilebileceği bilgisine yer verilmek suretiyle tüketicilerin yönlendirildiği; bu nedenle, "Tretin" adl ürünün örtülü reklamının yapıldığı değerlendirilmiș olup... mecra kuruluşu ... hakkında, 6502 sayılı Kanun'un 63 üncü ve 77/12 nci maddeleri uyarınca anlan reklamları durdurma cezası verilmesine karar verilmiştir." Reklam Kurulu, 2020/5051 nolu karar, 09.02.2021 tarih ve 306 sayılı toplantı, https://www.ticaret.gov.tr/tuketici/ticarireklamlar/reklam-kurulu-kararlari, Erişim Tarihi: 15.03.2021.

44 Kanun Numarası: 6502, Kabul Tarihi: 07.11.2013, RG: 28.11.2013/28835.

45 RG: 02.11.2011/28103.

46 Avrupa Sınırötesi Televizyon Sözleşmesinin Onaylanmasının Uygun Bulunduğuna Dair Kanun, Kanun Numarası: 3915 , Kabul Tarihi: 04.11.1993, RG: 07.11.1993/21751. 
olması gerektiği vurgulanmıştır. Milletlerarası Ticaret Odası tarafından kabul edilen Reklamcılık ve Pazarlama İletişimi Uygulama Esasları’nın ${ }^{47}$ genel ilke ve tanımlara ilişkin 1. bölümün 7 . maddesine göre pazarlama iletişimi açıkça ayırt edilebilir olmalı ve bir reklam editoryal bir içerikte görüntülenecekse reklam olduğu kolayca anlaşılabilecek şekilde sunulmalıdır.

Hukukumuzda 6112 sayılı Kanun ile ürün yerleştirme ile örtülü reklam arasında bir ayrım yapılmış ve Kanun'da öngörülen usul ve esaslara uygun olmak kaydıyla ürün yerleştirme uygulamasına izin verilmiştir. Kanun'un 13. maddesinin gerekçesinde "gizli ticari iletişsim, tüketiciler üzerindeki olumsuz etkisi nedeniyle genel olarak yasaklanmakla birlikte, bu kısttlama, izleyicinin ürün yerleștirmenin varlı̆̆ hakkında uygun bir şekilde bilgilendirildiği durumlarda uygulanmayacaktır" ifadeleriyle ürün yerleştirmenin örtülü reklam yasağının bir istisnası olduğunu vurgulamıştır.

\section{IV. ÜRÜN YERLEŞTIRMEYE ILIŞKIN USUL VE ESASLAR}

Ürün yerleştirme uygulaması uzun yıllardır uygulanagelen bir ticari iletişim türüdür. Ürün yerleştirmeye ilişkin kanuni düzenlemeler ise oldukça yeni tarihlidir. Hukukumuzda 2011 yılında 6112 sayılı Kanun’un yürürlüğe girmesiyle ürün yerleştirme uygulaması hukuki dayanağa kavuşmuştur. Bir ticari iletişim ancak Kanun ve Yönetmelik’te öngörülen usul ve esaslara uygun olması hâlinde ürün yerleştirme niteliği taşıyacaktır. Aksi takdirde örtülü reklam kapsamında değerlendirilerek ilgililer çeşitli idari yaptırımlarla karşı karşıya kalacaktır. Bu başlık altında ürün yerleştirme yapılırken dikkat edilmesi gereken düzenlemeler ve temel ilkeler ele alınacaktır.

\section{A. ÜRÜN YERLEŞTIRMEDE KULLANILAMAYACAK ÜRÜN VE HIZMETLER}

6112 sayılı Kanun ve ilgili Yönetmelik’te ürün yerleștirmede kullanılabilecek ürün ve hizmetlere dair çeşitli sınırlamalar getirilmiştir. Kanun’un 13/5 hükmü doğrultusunda ticarî iletişimi yasaklanmış ürünlerin ürün yerleştirmede de kullanılmasına izin verilmeyecektir. Ticari iletişimi yasaklanmış ürünler ise Kanun’un 11. maddesinde düzenlenmiştir. Bu maddeye göre alkol ${ }^{48}$ ve tütün ürünleri ile reçeteye tabi ilaç ve tedavilere ilişkin ticari iletişim yapilması yasaklanmıştır. Reçeteye tabi olmayan ilaç ve tedavilerin ticari iletişimine ise ancak söz konusu reklamların dürüstlük kuralı gözetilerek gerçeği yansıtan ve doğrulanması mümkün unsurlardan oluşması kaydıyla izin verilmiştir.

Yönetmelik’te ise Kanun’dan daha kapsamlı bir düzenleme getirilmiştir. Yönetmelik'in 12. maddesine göre, alkol ve tütün ürünleri ile reçeteye tabi ilaç ve tedavilere ilişkin yasağın yanı sıra ateşli veya

47 https://iccwbo.org/content/uploads/sites/3/2018/09/icc-advertising-and-marketing-communications-code-int.pdf, Erişim Tarihi: 14.03.2020.

48 “...Alkol kullanımı sırasında ekrana getirilen ürünün, içilen biranın zaman zaman yapılan yakın çekimlerle ön plana çıkarılmasılla, ürünü hatırlatıcı ve ürünün hatırda kalmasın să̆layıcı șekilde farklı sahnelerde sunulduğu görülmektedir. Bu yolla, ülkemizde bilinen ve tanınan ... bira markasının, ürün yerleștirme yoluyla reklamının yapıldiğı düşünülmektedir... Dolayısiyla dizi filmde yapilan bira markasina ait ürünün, ürün yerleștirmeye konu edilmesinin Kanun’u ihlal eder nitelikte olduğu açıktır..”"RTÜK, Toplantı No: 2015/16, Toplantı Tarihi: 07.04.2015, Karar No: 59, https://www.rtuk.gov.tr/ust-kurulkararlari/6112-sayili-kanunun-9-uncu-maddesinin-ucuncu-fikrasi-hukmunun-ihlali-nedeniyle-ipc-kanal-d-dtv-haberve-gorsel-yayincilik-a-s/7361?Aciklama=\%C3\%BCr\%C3\%BCn\%20yerle\%C5\%9Ftirme, Erişim Tarihi: 23.03.2021. 
ateşsiz her türlü silah, silah üreticisi veya satıcısının ${ }^{49}$; falcı, medyum, astrolog gibi kişilerce verilen hizmetlerin; eş ve arkadaş bulma hizmetlerinin ve özel kanunlarda reklamı yasaklanan mal ve hizmetlerin ticari iletişimine izin verilmeyecektir. Ayrıca gıda takviyesi, bitkisel ürünler, çeşitli cihazlar gibi ürünlerin ticari iletişimi sağlık beyanı ile ilaç olarak algılanmasına yol açmayacak şekilde yapılmalıdır.

Yönetmelik'te "genel beslenme diyetlerinde aşırı tüketimi tavsiye edilmeyen yă̆, yağa dönüşen asitler, tuz/sodyum ve şeker gibi gıda ve maddeleri içeren yiyecek ve içeceklerin” ticari iletişimine sınırlandırmalar getirilmiştir. Söz konusu ürünler Sağlık Bakanlığı tarafından tespit edilecek ve RTÜK'ün sitesinde ilan edilecektir ${ }^{50}$. Bu yiyecek ve içecekler için ürün yerleştirme yapılması durumunda Sağlık Bakanlığı tarafından tespit edilecek ve RTÜK’ün sitesinde ilan edilecek yazılı uyarıların akar bant şeklinde yayınlanması gerekmektedir. Bu uyarılar düzenli ve dengeli beslenmeyi teşvik edici nitelikte olmalıdır. Örneğin; "Sağlıklı beslenme; diyabet, kalp damar hastalıkları ve kanser gibi birçok hastalıktan korunmak için önemlidir", "Aşırı tuzlu, yağlı ve şekerli besinlerden kaçınınız", "Asitli ve gazlı içecekler yerine taze sıkılmıs meyve suyu, süt ve ayran gibi içecekleri tercih ediniz" $\mathrm{vb}^{51}$.

\section{B. ÜRÜN YERLEŞTIRMEYE YER VERILEBILECEK YAYINLAR}

Kanun'un 3. maddesinde ürün yerleştirme tanımlanırken ürün veya hizmetin bir "program" içerisine dahil edileceği düzenlenmiştir. "Program" ifadesinin kapsamı Kanun’un 13. maddenin 1. fikrasında düzenlenmiştir. Buna göre ürün yerleştirme sinema ve televizyon için yapılmış filmler, diziler ile spor ve genel eğlence programlarında yapılabilecektir" ${ }^{52}$. Özellikle sinema "uzaktan kumanda cihazının sağladığı ayrıcalıkları elinden alınmış izleyiciye doğrudan ulaşma şansı sağlaması yönünden"53 ürün yerleştirme için oldukça avantajlıdır. Olumsuz sonuçlar doğurma riski nedeniyle bazı yayın türlerinde ürün yerleştirme yapılması yasaklanmıştır. Bu kapsamda haber bültenlerinde, çocuk programlarında ve dinî programlarda ürün yerleştirmeye yer verilmesi mümkün değildir (6112 sayılı Kanun m. 13/4). Aksi halde örtülü reklam yasağı ihlal edilmiş olacaktır.

6112 sayılı Kanun'un 13. maddesinde ürün yerleştirmeye yer verilebilecek programlar arasında radyo yayınlarına yer verilmemiştir. Bu durum radyo yayınlarında ürün yerleştirmeye yapılıp yapılamayacağı

49 RTÜK, Toplantı No:2018/35, Toplantı Tarihi:06.09.2018, Karar No:28, https://www.rtuk.gov.tr/ust-kurul-kararlari/6112sayili-kanunun-13 uncu-maddesinin-besinci-fikrasinin-ihlali-nedeniyle-ipc-yaban-tv-ilk-kan-yayincilik-tanitimsanayi-ve-ticaret-a-s/25049?Aciklama=\%C3\%BCr\%C3\%BCn\%20yerle\%C5\%9Ftirme, Erişim Tarihi: 23.03.2021. https://www.rtuk.gov.tr/assets/Galeri/Haberler/besinprofiliklavuz.pdf, Erişim Tarihi: 27.03.2021.

https://www.rtuk.gov.tr/assets/Galeri/Haberler/akar-bant-yazilari.pdf, Erişim Tarihi: 27.03.2021.

52 “...6112 sayıl Kanun'da ürün yerleştirmenin sadece sinema ve televizyon için yapılmış filmler, diziler ile spor ve genel eğlence programlarıla sınırlandırıldığı, dolayısıyla, mezkur program tanıtımında bu uygulamaya yer verilmesi nedeniyle, 6112 sayılı Kanun’un 13'üncü maddesinin birinci fikrasının ihlal edildiği sabit görülmüştür...” RTÜK, Toplantı No: 2017/36, Toplantı Tarihi: 12.09.2017, Karar No: 10, https://www.rtuk.gov.tr/ust-kurul-kararlari/6112-sayili-kanunun13 uncu-maddesinin-birinci-fikrasinin-ihlali-nedeniyle-uyari-fox-huzur-radyo-tv-a-s/24127?Aciklama=\%C3\%BCr\%C3\%BCn\%20yerle\%C5\%9Ftirme, Erişim Tarihi: 23.03.2021; RTÜK, Toplantı No: 2012/36, Toplantı Tarihi: 12.06.2012, Karar No: 16, https://www.rtuk.gov.tr/ust-kurul-kararlari/6112-sayili-kanunun-13-uncu-maddesinin-birincifikrasindaki-sinema-ve-televizyon-icin-yapilmis-film/15273, Erişim Tarihi: 23.03.2021. 
hususunda duraksamaya neden olmaktadır. Uygulamadaki tereddütleri gidermek adına 2014 ylında Yönetmelik'in 14. maddesinde değişiklik yapılmış ${ }^{54}$ ve radyo yayınlarında da ürün yerleştirmeye yer verilebileceği düzenlenmiştir. Danıştay da "6112 sayılı Kanun'un 13. maddesinde program destekleyenin radyo yayınında ürün yerleştirme yapamayacağı yönünde bir kurala yer verilmediği, dolayısıla radyo yayınında program destekleyenin ürün yerleștirme yapabileceği, nitekim; radyo yayınlarında ürün yerleştirmenin nasıl, ne zaman ve hangi hususlara dikkat edilerek yapılacağının Yönetmelikte yapılan değişiklikle açıklğga kavuşturulduğu anlaşılmaktadır..." ifadeleriyle radyo programlarında ürün yerleştirme yapılabileceğini kabul etmektedir ${ }^{55}$. Öte yandan RTÜK, 2017 yılında verdiği bir kararında 6112 sayılı Kanunun 13/1 hükmünde ürün yerleştirme yapılabilecek programların tahdidi olarak sayıldığını, ilgili fikrada sayılmayan program tanıtımlarında ürün yerleştirme yapılamayacağını açıkça ifade etmiştir ${ }^{56}$. Dolayısıyla maddede sayılanlar haricinde bir programda ürün yerleştirme yapılması halinde örtülü reklam yasağı ihlal edilmiş sayılacaktır. Örtülü reklam yasağı 6112 sayılı Kanun ile kabul edildiği için bu kurala getirilecek istisnaların da yine kanunla düzenlenmesi gerekmektedir. $\mathrm{Bu}$ kapsamda radyo programlarında ürün yerleştirme yapılabilmesi için ilgili hüküm yönetmelikte değil kanunda yer almalıdır. Aksi halde radyo programlarında ürün yerleştirme adı altında yapılan reklam yayınlarının hukuki niteliği örtülü reklam olmaktan öteye gidemeyecektir.

\section{IZLEYICILERINÜRÜNYERLEŞTIRMENINVARLIĞIHAKKINDAAÇIKÇA BILGILENDIRILMESI}

Ürün yerleştirmeye ilişkin en önemli hususlardan biri ürün yerleştirme hakkında izleyicilerin açıkça bilgilendirilmesidir. Kanun’un açık hükmü karşısında izleyicilerin bildirilmesi yeterli değildir. İzleyicilerin "açıkça" bilgilendirilmesi gerekmektedir. Kanun'un 13. maddesinin 3. fikrasında bu bilgilendirmenin nasıl yapılacağı genel olarak düzenlenmiştir. Ayrıntılı düzenlemeler ise Yönetmelik'in 14. maddesinin 2. fikrasında yer almaktadır.

Ürün yerleştirmenin varlı̆̆ hakkında programın başında, sonunda ve reklam arası sonrasında program başladığında ${ }^{57}$ izleyicilerin bilgilendirilmesi gerekmektedir ${ }^{58}$. Bu bilgilendirme "Arial"

54 RG: 03.04.2014/28961.

55 D13D, T. 15.09.2015, E. 2015/4178, K. 2015/3140, Lexpera.

56 Bkz. Dipnot 52.

57 RTÜK bir kararında ihlale konu programın sadece başında ürün yerleştirme bilgilendirmesine yer verilmesinin 6112 sayılı Kanun'un 13. maddesine aykırı olduğuna hükmetmiştir. RTÜK, Toplantı No: 2019/18, Toplantı Tarihi: 24.04.2019, Karar No: 23, https:/www.rtuk.gov.tr/ust-kurul-kararlari/6112-sayili-kanunun-13uncu-maddesininucuncu-fikrasinin-ihlali-nedeniyle-kanunun-32nci-maddesinin-ikinci-fikrasi-uyarinca-idari-para-cezasi-kanal42-konevi-radyo-televizyon-yayincilik-a-s/26965?Aciklama=\%C3\%BCr\%C3\%BCn\%20yerle\%C5\%9Ftirme, Erişim Tarihi: 23.03.2021; Aynı yönde bkz. RTÜK, Toplantı No: 2019/03, Toplantı Tarihi: 09.01.2019, Karar No: 35, https:// www.rtuk.gov.tr/ust-kurul-kararlari/6112-sayili-kanunun-13uncu-maddesinin-ucuncu-fikrasinin-ihlali-nedeniylekanunun-32nci-maddesinin-ikinci-fikrasi-uyarinca-idari-para-cezasi-kanal-42-konevi-radyo-televizyon-yayincilik-as/26675?Aciklama=\%C3\%BCr\%C3\%BCn\%20yerle\%C5\%9Ftirme, Erişim Tarihi: 23.03.2021.

58 RTÜK, Toplantı No: 2014/09, Toplantı Tarihi: 05.02.2014, Karar No: 79, https://www.rtuk.gov.tr/ust-kurulkararlari/6112-sayili-kanunun-9-uncu-maddesinin-ucuncu-fikrasindaki-gizli-ticari-iletisime-izin-verilemezhukmunun-ihlali-360-tv-atlas-yayincilik-ve-ticaret-a-s/9270, Erişim Tarihi: 23.03.2021; RTÜK, Toplant1 No: 2012/07, Toplantı Tarihi: 01.02.2012, Karar No: 57, https://www.rtuk.gov.tr/ust-kurul-kararlari/6112-sayili-kanunun-13-uncumaddesinin-ucuncu-fikrasindaki-urun-yerlestirmede-urun-veya-hizmetlerin $/ 14700$ ? Aciklama=\%C3\%BCr\%C3\%BCn\%20yerle\%C5\%9Ftirme, Erişim Tarihi: 23.03.2021; D13D, T. 23.01.2015, E. 2013/3489, K. 2015/140, Lexpera. 
yazı tipinde, "Normal" yazı stili ve 15 piksel büyüklüğünde "Bu programda ürün yerleştirme bulunmaktadır." ifadesi yayınlanarak yapılacaktır. Bilgilendirme yazısı ekrandan akarak veya ekranda sabit bir yazıyla belirtilebilir. Her iki ihtimalde de önemli olan izleyicilerin bilgilendirilmesi ve ürün yerleştirmeyi yayından kolayca ayırt edebilmeleridir. Bu nedenle bilgilendirme yazısının izleyicilerin okuyabileceği hızda akması veya sabit yazının ekranda en az 10 saniye kalması gerekmektedir. Keza radyo yayınlarında yapılacak ürün yerleştirmelerde de programın başında, sonunda ve reklam arası sonrasında program başladığında dinleyicilerin sözlü olarak bilgilendirilmesi gerekmektedir. İzleyicilerin veya dinleyicilerin ürün yerleştirme hakkında bilgilendirilmemesi halinde ise örtülü reklam yasağ ihlal edilmiş olacaktır ${ }^{59}$.

\section{MEDYA HIZMET SAĞLAYICISININ EDITORYAL BAĞIMSIZLIĞI VE SORUMLULUĞU}

Medya hizmet sağlayıcısı, "radyo, televizyon ve isteğe bağl yayın hizmeti içeriğinin seçiminde editoryal sorumluluğu bulunan ve bu hizmetin düzenlenme ve yayınlanma biçimine karar veren tüzel kişiyi" ifade etmektedir (Kanun m. 3/1-1). Editoryal bağımsızlık, medya hizmet sağlayıcısının devletin ve medya sahibinin müdahalesi olmaksızın yayına dair karar alabilmesidir ${ }^{60}$. Editoryal sorumluluk ise "programların içeriği ve seçimi ile radyo ve televizyon yayın hizmetlerinde bir yayın akış çizelgesi, isteğe bağlı yayın hizmetlerinde ise bir katalog içinde sunulmasına ilişkin düzenleme ve kontrol yetkisine sahip olmayı" ifade etmektedir (Kanun m. 3/1-f).

Medya hizmet sağlayıcılarının editoryal bağımsızlı̆̆ı ve sorumluluğu 6112 sayılı Kanun'un 6. maddesinde güvence altına alınmıştır. Maddenin ilk fikrasına göre "yayın hizmetlerinin içeriğine ve yayınlanmasına önceden müdahale edilemez ve yayınların içeriği önceden denetlenemez"61. Editoryal

59 RTÜK, Toplantı No: 2013/49, Toplantı Tarihi:28.08.2013, Karar No: 92, https://www.rtuk.gov.tr/ust-kurul-kararlari/6112sayili-kanunun-9-uncu-maddesinin-ucuncu-fikrasindaki-gizli-ticari-iletisime-izin-verilemez-hukmunun-ihlaliem-tv-guclu-radyo-ve-televizyon-yayinciligi-prod-rek-tic-a-s/13495, Erişim Tarihi: 23.03.2021; RTÜK, Toplantı No: 2013/46, Toplantı Tarihi: 06.08.2013, Karar No: 67, https://www.rtuk.gov.tr/ust-kurul-kararlari/6112-sayili-kanunun9-uncu-maddesinin-ucuncu-fikrasindaki-gizli-ticari-iletisime-izin-verilemez-hukmunun-ihlali-e-haber-meg-medyaradyo-televizyon-ve-basin-yayincilik-a-s/13284, Erişim Tarihi: 23.03.2021; RTÜK, Toplantı No: 2013/27, Toplantı Tarihi: 30.04.2013, Karar No: 40, https://www.rtuk.gov.tr/ust-kurul-kararlari/6112-sayili-kanunun-9-uncu-maddesininucuncu-fikrasindaki-gizli-ticar-iletisime-izin-verilemez-ve12/11913, Erişim Tarihi: 23.03.2021; RTÜK, Toplantı No: 2013/58, Toplantı Tarihi: 23.10.2013, Karar No: 83, https://www.rtuk.gov.tr/ust-kurul-kararlari/6112-sayili-kanunun9-uncu-maddesinin-ucuncu-fikrasindaki-gizli-ticar-iletisime-izin-verilemez-hukmunun-ihlali-vizyon-turk-tv-kralkaradeniz-radyo-tv-yay-rek-hizm-san-tic-a-s/13974, Erişim Tarihi: 23.03.2021; RTÜK, Toplant1 No: 2012/03, Toplant1 Tarihi: 17.01.2012, Karar No: 28, https://www.rtuk.gov.tr/ust-kurul-kararlari/28-12-2011-tarihinde-tntde-yayinlanancarkifelek-adli-program-eko-tv-televizyon-yayincilik-a-s/14519, Erişim Tarihi: 23.03.2021.

60 TANSEL İLİC Deniz, “Türkiye’deki Anaakım Televizyon Kanallarında Editoryal Bağımsızlık -Profesyonellik İdeolojisi İlişkisi”, Gümüşhane Üniversitesi İletişim Fakültesi Elektronik Dergisi, C. 2, S. 4, 2014, s. 102; Doktrinde editoryal bağımsızlığın gerçekten sağlanamayacağı yönünde görüşler mevcuttur. YURDİGÜL Yusuf/YÜKSEL Hakan, “TV Haberciliğinde Editoryal Bağımsızlık Sorunu: Türkiye Televizyon Haberciliğinde Editoryal Bağımsızlık Sorununa İlişkin Alan Araştırması", Selçuk İletişim, C. 7, S. 4, 2013, s. 142-145.

616112 sayılı Kanun'un 6. maddesinin 4. fikrasına göre "Medya hizmet sağlayıcılar, ticarî iletişim ile üçüncü şahıslar tarafından üretilenler de dâhil olmak üzere, yayınlanan tüm yayın hizmetlerinin içeriğinden ve sunumundan sorumludur". ŞEN’e göre bu fıkra gerek Kanun’un "amaç” başlıklı ilk maddesiyle genel editoryal bağımsızlıkla gerekse aynı maddenin ilk fikrasıyla çelişmekte ve gizli bir sansür uygulamasına yol açmaktadır. ŞEN Ersan, "Radyo ve Televizyonların Yayın İçeriklerinden Sorumluluğu”, 01.01.2021, https://sen.av.tr/tr/makale/radyo-ve-televizyonlar\%C4\%B1n-yay\%C4\%B1n- 
bağımsızlık ürün yerleştirme uygulamasının bir diğer sınırını oluşturmaktadır. Buna göre ürün yerleştirme medya hizmet sağlayıcısının editoryal bağımsızlığını ve sorumluluğunu etkilememelidir.

Ürün yerleştirme yapılırken ürüne aşırı vurgu yapılması, ürün veya hizmetlerin kiralanması veya satın alınmasının doğrudan teşvik edilmesi genellikle medya hizmet sağlayıcısının editoryal bağımsızlı̆̆ ile bağdaşmayan sonuçlar doğurmaktadır. RTÜK’ün önüne gelen uyuşmazlıklarda bu iki hususunun sıklıkla iç içe geçtiği görülmektedir. RTÜK’ün 09.01.2019 tarihindeki toplantıda verdiği 35 sayılı kararına konu olan uyuşmazlık bu duruma örnektir. Uyuşmazlık özel bir televizyon kanalında "Asfora Kapinızda" isimli programdan kaynaklanmaktadır. Programda sunucu ev sahiplerine Asfora'dan alışveriş yapıp yapmadıklarını sormakta ve Asfora’dan alışveriş yaptıklarını ispatlamaları hâlinde 25 TL vereceğini söylemektedir. Ayrıca program içerisinde Asfora’ya ait logo, slogan ve reklam müziği de yer almaktadır. RTÜK yaptığı inceleme neticesinde programın açık ve net bir şekilde Asfora için özel olarak hazırlandığı, editoryal bağımsızlığın ihlal edildiğini ve programın tamamında Asfora’ya ve ürünlerine aşırı vurgu yapılarak Asfora’dan alışveriş yapılması teşvik edildiği sonucuna ulaşmış ve medya hizmet sağlayıcısına idari para cezası vermiştir ${ }^{62}$.

\section{E. ÜRÜN YERLEŞTIRMENIN IÇERIĞi}

Bir yayında yer verilen ürün yerleştirmenin kapsamı ve sınırlarının nasıl tespit edileceğine dair Kanun ve Yönetmelik ile iki temel ölçüt kabul edilmiştir: Ürün veya hizmetlerin kiralanması veya satın alınması doğrudan teşvik edilememesi ve ürüne aşırı vurgu yapılamaması ${ }^{63}$. Bu ölçütler ile

iceriklerinden-sorumlulugu, Erişim Tarihi: 17.03.2021.

62 RTÜK, Toplantı No: 2019/03, Toplantı Tarihi: 09.01.2019, Karar No:35, https://www.rtuk.gov.tr/ust-kurul-kararlari/6112sayili-kanunun-13uncu-maddesinin-ucuncu-fikrasinin-ihlali-nedeniyle-kanunun-32nci-maddesinin-ikinci-fikrasiuyarinca-idari-para-cezasi-kanal-42-konevi-radyo-televizyon-yayincilik-a-s/26675, Erişim Tarihi: 23.03.2021; Aynı programa ilişkin aynı yönde bir başka karar için bkz. RTÜK, Toplantı No: 2018/52, Toplantı Tarihi: 26.12.2018, Karar No: 35, https://www.rtuk.gov.tr/ust-kurul-kararlari/6112-sayili-kanunun-13uncu-maddesinin-ucuncu-fikrasinin-ihlalinedeniyle-kanunun-32nci-maddesinin-ikinci-fikrasi-uyarinca-idari-para-cezasi-kanal-42-konevi-radyo-televizyonyayincilik-a-s/26551?Aciklama=\%C3\%BCr\%C3\%BCn\%20yerle\%C5\%9Ftirme, Erişim Tarihi: 23.03.2021.

63 RTÜK, Toplant1 No: 2014/39, Toplant1 Tarihi: 16.07.2014, Karar No: 54, https://www.rtuk.gov.tr/ust-kurulkararlari/6112-sayili-kanunun-13-uncu-maddesinin-ucuncu-fikrasinda-belirtilen-urun-yerlestirmede-urun-veyahi/9975?Aciklama $=\% \mathrm{C} 3 \% \mathrm{BCr} \% \mathrm{C} 3 \% \mathrm{BCn} \% 20 y e r l e \% C 5 \% 9 F t i r m e$, Erişim Tarihi: 23.03.2021; RTÜK, Toplantı No: 2014/15, Toplantı Tarihi:04.03.2014, Karar No: 124, https://www.rtuk.gov.tr/ust-kurul-kararlari/6112-sayili-kanunun-13uncu-maddesinin-ucuncu-fikrasinda-belirtilen-urun-yerlestirmede-urun-veya-hi/8948? Aciklama=\%C3\%BCr\%C3\%BCn\%20yerle\%C5\%9Ftirme, Erişim Tarihi: 23.03.2021; RTÜK, Toplantı No: 2014/07, Toplantı Tarihi: 29.01.2014, Karar No: 77, https://www.rtuk.gov.tr/ust-kurul-kararlari/6112-sayili-kanunun-13-uncu-maddesinin-ucuncufikrasinda-belirtilen-urun-yerlestirmede-urune-asiri-vurgu-yapilamaz-hukmunun-ihlali-kanal-d-dtv-haber-ve-gorselyayincilik-a-s/9208, Erişim Tarihi: 23.03.2021, (Söz konusu karar Ankara 4. İdare Mahkemesinin 17.12.2014 tarih ve E. 2014/699, K. 2014/1742 sayılı kararıyla iptal edilmiştir. Ancak temyiz incelemesinde Danıştay ürüne aşırı vurgu yapıldığını ifade ederek Ankara 4. İdare Mahkemesinin kararını bozmuştur. D13D, T. 16.05.2018, E. 2015/1580, K. 2018/1729, Lexpera); RTÜK, Toplantı No: 2014/07, Toplant1 Tarihi: 29.01.2014, Karar No: 78, https://www.rtuk.gov. tr/ust-kurul-kararlari/6112-sayili-kanunun-13-uncu-maddesinin-ucuncu-fikrasinda-belirtilen-urun-yerlestirmedeurun-veya-hi/9209?Aciklama=\%C3\%BCr\%C3\%BCn\%20yerle\%C5\%9Ftirme, Erişim Tarihi: 23.03.2021; RTÜK, Toplantı No: 2012/57, Toplantı Tarihi: 11.10.2012, Karar No: 31, https:/www.rtuk.gov.tr/ust-kurul-kararlari/6112sayili-kanunun-13-uncu-maddesinin-ucuncu-fikrasinda-urun-yerlestirmenin-medya-hizmet-saglayici/15429, Erişim Tarihi: 23.03.2021, (Söz konusu karar D13D, T. 23.01.2015, E. 2013/1927, K. 2015/143 sayll kararla hukuka uygun bulunmuştur. Lexpera); RTÜK, Toplantı No: 2012/41, Toplantı Tarihi: 11.07.2012, Karar No: 38, https://www.rtuk.gov. 
ürün yerleştirmeye konu olan ürün veya hizmetlere programın bütünlüğünü bozmaksızın adeta programın bir parçasıymışçasına yer verilmesi amaçlanmaktadır ${ }^{64}$. Bu nedenle ürün yerleştirme yapılırken yayın esnasında söz konusu ürün veya hizmete ilişkin bant reklamı yapılamayacaktır. Keza ürün yerleștirme yapılırken ses seviyesi yayının diğer bölümlerinin ses seviyesinden farklı olmamalıdır (Yönetmelik m.9/8).

Uygulamada ürün yerleştirme konusunda yaşanan uyuşmazlıkların büyük bir kısmı ürüne aşırı vurgu yapılmasından kaynaklanmaktadır. Kanun'da geçen "aşırı" ifadesi yoruma muhtaçtır. RTÜK kararlarında da ürüne aşırı vurgu yapılıp yapılmadığı konusunda görüş ayrılıkları bulunduğu görülmektedir ${ }^{65}$. Bir RTÜK kararının karşı oyunda belirtildiği gibi “Ürün yerleştirme uygulaması olan

tr/ust-kurul-kararlari/6112-sayili-kanunun-13-uncu-maddesinin-ucuncu-fikrasindaki-urun-yerlestirmenin-medyahizmet-saglayi/15328?Aciklama=\%C3\%BCr\%C3\%BCn\%20yerle\%C5\%9Ftirme, Erişim Tarihi: 23.03.2021, (Söz konusu karar D13D, T. 15.02.2018, E. 2014/245, K. 2018/508 sayıl kararla hukuka uygun bulunmuştur. Lexpera); RTÜK, Toplant1 No: 2012/11, Toplant1 Tarihi: 16.02.2012, Karar No: 44, https://www.rtuk.gov.tr/ust-kurul-kararlari/6112sayili-kanunun-13uncu-maddesinin-ucuncu-fikrasindaki-urun-yerlestirmede-urune-asiri-vurgu-yapilamazhukmunun-ihlali-star-tv-isil-televizyon-yayincilik-yap-san-ve-tic-a-s/14791?Aciklama $=\% \mathrm{C} 3 \% \mathrm{BCr} \% \mathrm{C} 3 \% \mathrm{BCn} \% 20$ yerle\%C5\%9Ftirme, Erişim Tarihi: 23.03.2021, (Söz konusu karar D13D, T. 11.03.2014, E. 2013/1037, K. 2014/840 sayılı kararla hukuka uygun bulunmuştur. https://legalbank.net/belge/d-13-d-e-2013-1037-k-2014840-t-11-03-2014/1406786/, Erişim Tarihi: 23.03.2021); RTÜK, Toplantı No: 2015/53, Toplantı Tarihi: 10.12.2015, Karar No: 56, https://www.rtuk.gov.tr/ust-kurul-kararlari/6112-sayili-kanunun-13-uncu-maddesinin-ucuncufikrasi-hukmunun-ihlali-nedeniyle-idari-para-cezasi-uygulanmasi-kanal-d-dtv-haber-ve-gorsel-yayincilik-as/8388? Aciklama=\%C3\%BCr\%C3\%BCn\%20yerle\%C5\%9Ftirme, Erişim Tarihi: 23.03.2021; RTÜK, Toplantı No: 2015/06, Toplantı Tarihi: 04.02.2015, Karar No: 57, https://www.rtuk.gov.tr/ust-kurul-kararlari/6112-sayili-kanunun13-uncu-maddesinin-ucuncu-fikrasi-hukmunun-ihlali-nedeniyle-uyari-best-fm-best-production-yayincilik-a-s/ 7077? Aciklama=\%C3\%BCr\%C3\%BCn\%20yerle\%C5\%9Ftirme, Erişim Tarihi: 23.03.2021; RTÜK, Toplantı No: 2015/02, Toplantı Tarihi: 14.01.2015, Karar No: 112, https://www.rtuk.gov.tr/ust-kurul-kararlari/6112-sayili-kanunun-13-uncumaddesinin-ucuncu-fikrasi-hukmunun-ihlali-nedeniyle-idari-para-cezasi-uygulanmasi-fox-huzur-radyo-televizyona-s/6917?Aciklama=\%C3\%BCr\%C3\%BCn\%20yerle\%C5\%9Ftirme, Erişim Tarihi: 23.03.2021; D13D, T. 23.01.2015, E. 2013/2390, K. 2015/139, Lexpera.

64 “...İhlale konu spor programda; ürün yerleștirme çerçevesinde ekrana getirilen ürünlerin görüntülerine sık aralklarla yer verilerek ürünlere aşırı vurgu yapıldığı, programın doğal akışını ve bütünlüğünün bozulduğu, ürünlerin tanıtımın yaparak, bahse konu görüntülerde reklam izleniminin baskın olduğu kanaatine varllmıştır..."RTÜK, Toplantı No: 2018/30, Toplantı Tarihi: 25.07.2018, Karar No: 63, https://www.rtuk.gov.tr/ust-kurul-kararlari/6112-sayili-kanunun-13uncumaddesinin-ucuncu-fikrasinin-ihlali-nedeniyle-idari-para-cezasi-beyaz-tv-kanal-beyaz-televizyon-radyo-yayinciliksanayi-ve-ticaret-a-s/24955?Aciklama $=\% \mathrm{C} 3 \% \mathrm{BCr} \% \mathrm{C} 3 \% \mathrm{BCn} \% 20$ yerle\%C5\%9Ftirme, Erişim Tarihi: 23.03.2021; Aynı yönde bkz. RTÜK, Toplantı No: 2018/16, Toplantı Tarihi: 18.04.2018, Karar No: 65, https://www.rtuk.gov.tr/ ust-kurul-kararlari/6112-sayili-kanunun-13uncu-maddesinin-ucuncu-fikrasinin-ihlali-nedeniyle-idari-para-cezasistar-tv-startv-medya-hizmetleri-a-s/24784? Aciklama $=\% \mathrm{C} 3 \% \mathrm{BCr} \% \mathrm{C} 3 \% \mathrm{BCn} \% 20 y e r l e \% \mathrm{C} 5 \% 9$ Ftirme, Erişim Tarihi: 23.03.2021; RTÜK, Toplantı No: 2017/24, Toplantı Tarihi: 13.06.2017, Karar No: 78, https://www.rtuk.gov.tr/ust-kurulkararlari/6112-sayili-kanunun-13uncu-maddesinin-ucuncu-fikrasinin-ihlali-nedeniyle-idari-para-cezasi-show-tv-akstelevizyon-rek-ve-film-san-ve-tic-a-s/23883?Aciklama $=\% \mathrm{C} 3 \% \mathrm{BCr} \% \mathrm{C} 3 \% \mathrm{BCn} \% 20 y e r l e \% \mathrm{C} 5 \% 9$ Ftirme, Erişim Tarihi: 23.03.2021.

65 RTÜK, Toplantı No:2015/06, Toplantı Tarihi: 04.02.2015, Karar No:57, https://www.rtuk.gov.tr/ust-kurul-kararlari/6112sayili-kanunun-13-uncu-maddesinin-ucuncu-fikrasi-hukmunun-ihlali-nedeniyle-uyari-best-fm-best-productionyayincilik-a-s/7077, Erişim Tarihi: 23.03.2021; RTÜK, Toplantı No: 2015/49, Toplantı Tarihi: 18.11.2015, Karar No: 35, https://www.rtuk.gov.tr/ust-kurul-kararlari/6112-sayili-kanunun-13-uncu-maddesinin-ucuncu-fikrasi-hukmununihlali-nedeniyle-ipc-kanal-d-dtv-haber-ve-gorsel-yayincilik-a-s/8342? Aciklama $=\% \mathrm{C} 3 \% \mathrm{BCr} \% \mathrm{C} 3 \% \mathrm{BCn} \% 20$ yerle\%C5\%9Ftirme, Erişim Tarihi: 23.03.2021; RTÜK, Toplantı No: 2015/53, Toplantı Tarihi: 10.12.2015, Karar No: $\quad 56$, https://www.rtuk.gov.tr/ust-kurul-kararlari/6112-sayili-kanunun-13-uncu-maddesinin-ucuncu-fikrasihukmunun-ihlali-nedeniyle-idari-para-cezasi-uygulanmasi-kanal-d-dtv-haber-ve-gorsel-yayincilik-a-s/8388, Erişim Tarihi: 23.03.2021; RTÜK, Toplantı No: 2016/02, Toplantı Tarihi: 06.01.2016, Karar No: 11, https://www.rtuk. 
programlarda; "Programın içerisine yerleştirilen ürün, programın bir parçasıymış gibi doğal mecrasında kullanılmalıdır." hükmü o programı izleyen uzmana göre değişkenlik arz etmektedir. Dolayısıyla çoğu zaman bu tür değerlendirmeler sübjektif ölçüde kalmaktadır’66.

Yerleştirilen ürün veya hizmete aşırı vurgu yapılıp yapılmadığı somut olayın özellikleri doğrultusunda her uyuşmazlıkta ayrıca değerlendirilecektir. Bununla birlikte ürün yerleştirme yapılırken bazı eylemlerin Yönetmelik’te açıkça yasaklandığı görülmektedir. Buna göre ürün yerleştirmeye konu olan ürün ve hizmetlerin tekrarlar halinde gösterilmesi veya özelliklerinin övülmesi, belli bir ürün veya hizmete yönelik tercih bildirilmesi, ürün veya hizmet hakkında ayrıntılı bilgi verilmesi ${ }^{67}$ ve çeşitli çekim teknikleriyle ürünün ön plana çıkarılması ${ }^{68}$ yasaklanmıştır $^{69}$ (Yönetmelik, m. 14/3). $\mathrm{Bu}$ yasakların ihlal edilmesi, yerleştirilen ürün veya hizmete aşırı vurgu yapılması anlamına gelmektedir ${ }^{70}$.

gov.tr/ust-kurul-kararlari/6112-sayili-kanunun-13-uncu-maddesinin-ucuncu-fikrasinin-ihlali-nedeniyle-idaripara-cezasi-uygulanmasi-kanal-d-dtv-haber-ve-gorsel-yayincilik-a-s/6242? Aciklama $=\% \mathrm{C} 3 \% \mathrm{BCr} \% \mathrm{C} 3 \% \mathrm{BCn} \% 20$ yerle\%C5\%9Ftirme, Erişim Tarihi: 23.03.2021.

66 RTÜK, Toplant1 No: 2018/20, Toplant1 Tarihi: 15.05.2018, Karar No: 18, https://www.rtuk.gov.tr/ust-kurulkararlari/6112-sayili-kanunun-13uncu-maddesinin-ucuncu-fikrasinin-ihlali-nedeniyle-idari-para-cezasi-fox-huzurradyo-tv-a-s/24823?Aciklama=\%C3\%BCr\%C3\%BCn\%20yerle\%C5\%9Ftirme, Erişim Tarihi: 23.03.2021.

67 RTÜK, Toplant1 No: 2013/32, Toplant1 Tarihi: 22.05.2013, Karar No: 70, https://www.rtuk.gov.tr/ust-kurulkararlari/6112-sayili-kanunun-13-uncu-maddesinin-ucuncu-fikrasinda-belirtilen-urun-yerlestirmede-urun-veyahi/12419?Aciklama=\%C3\%BCr\%C3\%BCn\%20yerle\%C5\%9Ftirme, Erişim Tarihi: 23.03.2021.

68 RTÜK, Toplant1 No: 2012/52, Toplant1 Tarihi: 19.09.2012, Karar No: 41, https://www.rtuk.gov.tr/ust-kurulkararlari/6112-sayili-kanunun-12-nci-maddesinin-dorduncu-fikrasindaki-haber-bulteni-ve-din-toren-yayinlarinda/15 386? Aciklama=\%C3\%BCr\%C3\%BCn\%20yerle\%C5\%9Ftirme, Erişim Tarihi: 23.03.2021.

69 “...Ihlale konu programda, suyun doğal kaynak su olmasından bahsedilerek suyun özelliklerinin anlatıldığı, PH değerinin yüksek olmasına vurgu yapılarak ürünün olumlu yanlarına dikkat çekildiği ve ürüne övgüler yapılarak ürünün açık bir şekilde tanıtımının yapıldığı, yine vatandaşlarla yapılan diyaloglar sırasında, sunucunun, ürünü elinde tutarak gösterdiği ve zaman zaman da ekranin sağ tarafinda suyun farklı ambalajlardaki çeşitlerinin ekranda gösterildiği, bununla birlikte sadece programın başında "Bu programda ürün yerleștirme bulunmaktadır." ibaresine yer verilmiş ise de, saat 20.54 'teki reklam sonrasinda ve programin sonunda bu ibareye yer verilmediği, dolaylstyla mezkur programda, reklam arası sonrasında program başladığında, ürün yerleştirmenin varllğı hakkında açıkça bilgilendirilmediği ve ürüne aşırı vurgu yapılarak fazlasılla ön plana çıkarıldığı kanaatine varılmıştır..."RTÜK, Toplantı No: 2018/47, Toplantı Tarihi: 22.11.2018, Karar No: 37, https://www.rtuk.gov.tr/ust-kurul-kararlari/6112-sayili-kanunun-13uncu-maddesininucuncu-fikrasinin-ihlali-nedeniyle-kanunun-32nci-maddesinin-ikinci-fikrasi-uyarinca-idari-para-cezasigaziantepolay-tvgaziantep-olay-yayincilik-a-s/26433?Aciklama $=\% \mathrm{C} 3 \% \mathrm{BCr} \% \mathrm{C} 3 \% \mathrm{BCn} \% 20$ yerle $\% \mathrm{C} 5 \% 9$ Ftirme, Erişim Tarihi: 23.03.2021; "...İhlale konu dizide; ürün yerleştirme çerçevesinde 5 farkl sahnede ekrana getirilen ürünün görüntülerine övücü ifadelerle yer verilerek ürüne aşırı vurgu yapıldığı, ürünü içeren sahnelerin fazla uzatıllp ve kameranın özellikle ürüne odaklanarak programın doğal akışı ve bütünlüğünün bozulduğu, ürünün reklamlarında kullanılan ifadelerin ve içeriklerin ürün yerleştirmede de kullanıldı̆̆ı ve bahse konu görüntülerde ürünün fazlasılyla ön plana çıkarıldığı kanaatine varılmıştır..."RTÜK, Toplantı No: 2018/32, Toplantı Tarihi: 08.08.2018, Karar No: 24, https:// www.rtuk.gov.tr/ust-kurul-kararlari/6112-sayili-kanunun-13uncu-maddesinin-ucuncu-fikrasinin-ihlali-nedeniyleidari-para-cezasi-fox-tv-huzur-radyo-tv-a-s/24984? Aciklama=\%C3\%BCr\%C3\%BCn\%20yerle\%C5\%9Ftirme, Erişim Tarihi: 23.03.2021; Aynı yönde bkz. RTÜK, Toplantı No: 2016/02, Toplantı Tarihi: 06.01.2016, Karar No: 11, https:// www.rtuk.gov.tr/ust-kurul-kararlari/6112-sayili-kanunun-13-uncu-maddesinin-ucuncu-fikrasinin-ihlali-nedeniyleidari-para-cezasi-uygulanmasi-kanal-d-dtv-haber-ve-gorsel-yayincilik-a-s/6242, Erişim Tarihi: 23.03.2021; D13D, T. 23.01.2015, E. 2013/1310 K. 2015/142, Lexpera.

70 RTÜK, Toplantı No: 2017/49, Toplant1 Tarihi: 07.12.2017, Karar No: 34, https://www.rtuk.gov.tr/ust-kurulkararlari/6112-sayili-kanunun-13uncu-maddesinin-ucuncu-fikrasinin-ihlali-nedeniyle-ipc-star-arti-fm-kamer-radyotelevizyon-yayincilik-hizmetleri-sanayi-ve-ticaret-a-s/24400?Aciklama=\%C3\%BCr\%C3\%BCn\%20yerle\%C5\%9Ftirme, Erişim Tarihi: 23.03.2021. 


\section{F. BIR SAATLIK YAYINDA YER VERILEBILECEK ÜRÜN YERLEŞTIRME SINIRI}

Bir saat başından bir sonraki saat başına kadar süren yayın süresi içerisinde yer verilebilecek ürün yerleştirmeler için sayı sınırlaması bulunmamaktadır. Yönetmelik'in ilk halinde 14. maddenin 5. fıkrasında, bir saatlik bir yayında en fazla dört tane ürün yerleştirme sınırı mevcuttu. Uygulamada ise bu yasak sık sık ihlal edilmekte ve bir saatlik yayında ortalama beş-altı ürün yerleştirme yapıldığ görülmekteydi ${ }^{71}$. 03.04.2014 tarihinde Resmi Gazete'de yayımlanan Yayın Hizmeti Usul ve Esasları Hakkında Yönetmelikte Değişiklik Yapılmasına Dair Yönetmelik ile söz konusu hüküm ilga edilmiştir. Günümüzde bir saatlik yayın esnasında Kanun ve Yönetmelik’te öngörülen usul ve esaslara uygun olmak kaydıyla dörtten fazla ürün yerleştirmeye yer verilmesi mümkündür.

Bir saatlik yayın süresi içinde yer verilebilecek ürün yerleştirmeler için süre sınırlaması da bulunmamaktadır. Kanun'un 10. maddesinin 2. fikrasına göre bir saatlik yayında reklam yayınlarının oranı \%20'den fazla olamayacaktır. Diğer bir ifadeyle bir saatlik yayında en fazla 12 dakika reklama yer verilebilir. Her ne kadar ürün yerleştirme temelde bir reklam türü olarak kabul edilse de Kanun'un 10. maddesinin 3. fikrasına göre 12 dakikalık süreye program desteklemesi, yayıncının kendi programlarının tanıtımları ve ürün yerleştirmeye ayrılan süre dahil değildir. Ancak bu hüküm bir ürün veya hizmet için ürün yerleştirme yapılan sürenin sınırsız olduğu anlamına gelmemektedir. Aksi halde söz konusu ürün veya hizmete aşırı vurgu yapılması riskiyle karşı karşıya kalınacaktır.

\section{G. TICARi iLETişiME ILIŞKIN TEMEL ILKELER}

Ürün yerleştirme, ticari iletişimin türlerinden biridir. Ürün yerleştirmenin 6112 sayılı Kanun'un 13. maddesinde öngörülen usul ve esasların yanı sıra ticari iletişime ilişkin Kanun ${ }^{72}$

71 Elif KOÇAK, ““Ürün yerleştirme”'ye ilgi artıyor”, T. 08.05.2012, Anadolu Ajansı, https://www.aa.com.tr/tr/yasam/urunyerlestirmeye-ilgi-artiyor/369518, Erişim Tarihi: 17.03.2021.

726112 sayll Kanun'un 9. maddesine göre:

"Genel esaslar

MADDE 9 - (1) Ticarî iletişim, yayın hizmetinin diğer unsurlarından görsel ve işitsel olarak kolayca ayırt edilebilir olmak zorundadir.

(2) Ticarî iletişimde bilinçaltı teknikleri kullanılamaz.

(3) Gizli ticarî iletişime izin verilemez.

(4) Haber bülteni ve haber programların düzenli olarak sunan kişilerin görüntü veya seslerine ticarî iletişimlerde yer verilemez.

(5) Ticarî iletişim, medya hizmet sağlayıcının editoryal bağımsızlığını ve program içeriğini etkileyecek şekilde kullanılamaz.

(6) Ticarî iletişim, 8 inci maddede belirlenen esas ve ilkeler sakl kalmak kaydıyla;

a) Adalet, hakkaniyet ve dürüstlük ilkelerine uygun olmak,

b) Cinsiyet, ırk, renk veya etnik köken, tabiiyet, din, felsefî inanç veya siyasî düşünce, engellilik, yaş ve herhangi bir ayrımcılığ 1 içermemek veya teşvik etmemek, (1)

c) Yanıltıcı olmamak ve tüketicinin çıkarlarına zarar vermemek,

ç) Çocukların fiziksel, zihinsel veya ahlakî gelişimine zarar vermemek, deneyimsizliklerini veya saflıklarını istismar ederek, çocukları bir ürün veya hizmeti satın almaya veya kiralamaya doğrudan yönlendirmemek; çocukları reklamı yapılmakta olan ürün veya hizmetleri satın almak için ebeveynlerini veya başkaların ikna etmeye doğrudan teşvik etmemek; çocukların ebeveynlerine, ögretmenlerine veya diğer kişilere duyduğu güveni istismar etmemek veya sebepsiz olarak çocukları tehlikeli durumlarda göstermemek,

d) Kadınların istismarına yönelik olmamak,

e) Sağlık, çevre ve güvenliğe zarar verecek davranışa teşvik etmemek,zorundadır. 
ve Yönetmelik'te ${ }^{73}$ yer alan temel ilkelere de uygun olması gerekmektedir. Aksi halde Kanun'da öngörülen yaptırımlarla karşı karşıya kalınacaktır.

\section{V. ÜRÜN YERLEŞTIRME USUL VE ESASLARINA AYKIRILIK VE IDARI YAPTIRIMLAR}

Ürün yerleştirme yapılırken mevzuatta öngörülen usul ve esaslara aykırı hareket edilmesi halinde Kanun'un 32. maddesinde öngörülen idari para cezası yaptırımı uygulanacaktır. Bu hükme göre Kanun'da öngörülen ilke, yükümlülük ve yasaklara aykırı hareket eden medya hizmet sağlayıcısına ihlalin ağırlı̆̆ı, yayının ortamı ve alanı göz önünde bulundurularak, ihlalin tespit edildiği aydan bir önceki aydaki brüt ticari iletişim gelirinin yüzde birinden yüzde üçüne kadar RTÜK tarafından idari para cezası verilecektir. Bu kapsamda verilecek idari para cezaları televizyon kuruluşları ve isteğe bağlı medya hizmet sağlayıcıları için 10.000-TL'den, radyo kuruluşları için ise 1.000-TL'den az olmayacaktır. Ancak Üst Kurul ihlalin ağırlığı, haksız ekonomik kazancın ve tekrarın varlığı ile son beş yılda uygulanan idari yaptırımları dikkate alarak her bir ihlal için bir defaya mahsus olmak üzere idari para cezası uygulamak yerine medya hizmet sağlayıcı kuruluşu uyarabilir (6112 sayılı Kanun m.32/8). Hükmün ilk halinde yayın yapan medya hizmet sağlayıcılarının ürün yerleștirmede Kanun'da öngörülen usul ve esaslara aykırı hareket etmesi halinde önce uyarılacağı, uyarının ilgiliye tebliğinden sonra ihlalin tekrarı halinde ise idari para cezası ile cezalandırılacağı düzenlenmişti. 690 sayılı $\mathrm{KHK}^{74}$ ile bu uygulamaya son verilmiştir.

Medya hizmet sağlayıcısının Kanun'un 32/2 hükmü uyarınca idari para cezası ile cezalandırılmalarına ilişkin kararın tebliğinden itibaren bir yıl içerisinde Kanun'un ticari iletişsime dair hükümlerinden herhangi birini yirmiden fazla ihlal etmesi halinde beş güne kadar yayın durdurma cezası verilecektir. Aynı ihlalin bir yıl içerisinde tekrar edilmesi halinde beş günden on güne kadar yayın durdurma cezası verilecektir. Bu yaptırımlara rağmen Kanuna aykırı yayın yapmaya devam eden medya hizmet sağlayıcılarının yayın lisansları iptal edilecektir (6112 sayılı Kanun m. 32/5).

6112 sayılı Kanun kapsamında verilen idari yaptırım kararlarına karşı açlacak davalarda idari yargı kolu görevlidir (6112 sayılı Kanun m. 32/9). Kararın hukuka aykırı olduğunu düşünen ilgililer Kanun'da öngörülen 15 günlük özel dava açma süresi içerisinde idari yargıda iptal davası açabilir. Açlacak davalarda yetkili ve görevli mahkeme Ankara idare mahkemeleridir. İlgililer dilerse dava açmadan önce kararın kendilerine tebliğinden itibaren dava açma süresi içerisinde İdari Yargılama Usul Kanunu’nun ${ }^{75} 11$. maddesi uyarınca RTÜK’e başvurarak söz konusu kararın kaldırılmasını, geri alınması, değiştirilmesi veya yeni bir işlem yapılmasını isteme imkanına sahiptir.

(7) Genel beslenme diyetlerinde aşırı tüketimi tavsiye edilmeyen gıda ve maddeler içeren yiyecek ve içeceklerin ticarî iletişimine, çocuk programlarıla birlikte veya bu programların içinde yer verilemez.

(8) Ticarî iletişim yayınlarının ses seviyesi diğer yayın bölümleri ile aynı seviyede olmak zorundadır."

73 Bkz. Yönetmelik m. 9.

74 Olağanüstü Hal Kapsamında Bazı Düzenlemeler Yapılması Hakkında Kanun Hükmünde Kararname, KHK No: 690, RG: 29.04.2017/30052.

75 Kanun Numarası: 2577, Kabul Tarihi: 06.01.1982, RG: 20.01.1982/17580. 


\section{SONUÇ}

Ürün yerleştirme, geleneksel reklam stratejilerinin zayıfladığı günümüz piyasasında vazgeçilmez bir yere sahiptir. Ürün yerleştirme; dizi ve filmlere gerçeklik kazandırmakta, yüksek bütçeli yapımların çekilmesine finansal kaynak yaratmakta, reklam kuşaklarıyla ulaşılamayan kişilere reklamın mesajının iletilmesini sağlamakta ve reklamı yapılan ürünü kullanan karaktere kendini yakın hisseden izleyicilerle ürün arasında duygusal bağ kurmaktadır.

Kanun'da ve uluslararası belgelerde örtülü reklam/gizli ticari iletişim açıkça yasaklanmıştır. 6112 sayılı Kanun öncesinde ürün yerleştirme uygulamaları da gizli ticari iletişim kapsamında değerlendirilmiş ve ilgili medya hizmet sağlayıcısı idari yaptırımlarla karşı karşıya kalmıştır. 6112 sayılı Kanun ile ürün yerleştirme uygulaması hukuki temele kavuşturulmuştur. Günümüzde 6112 sayılı Kanun ve ilgili Yönetmelik’te öngörülen usul ve esaslara uygun olmak kaydıyla ürün yerleştirmeye yer verilmesi mümkündür.

Ürün yerleştirme hususunda uygulamada uyuşmazlıkların yoğunlaştığı nokta ürüne aşırı vurgu yapılıp yapılmadığıdır. Ürüne aşırı vurgu yapılması programın doğal akışını bozacak şekilde reklamı yapılan ürünün ön plana çıkarılmasıdır. Yönetmelikte ürünü ön plana çıkarmak için farklı çekim tekniklerinin kullanılması, ürün veya hizmet hakkında ayrıntılı bilgilerin verilmesi, ürün veya hizmetin övülmesi gibi haller açıkça yasaklanmıştır. Ancak ürün veya hizmete aşırı vurgu yapılması her somut olayda kolaylıkla ayırt edilebilecek nitelikte değildir. Uygulamada da RTÜK’ün kararlarının önemli bir kısmını oy birliğiyle değil oy çokluğuyla vermesi dikkat çekmektedir.

6112 sayılı Kanun ve ilgili Yönetmelik’te öngörülen usul ve esaslara aykırı şekilde ürün yerleştirme yapılması halinde medya hizmet sağlayıcısı Kanun'un 32. maddesinde düzenlenen başta idari para cezası olmak üzere çeşitli yaptırımlarla karşı karşıya kalacaktır. RTÜK tarafından tesis edilen cezanın hukuka aykırı olduğunu düşünen ilgililer 15 günlük özel dava açma süresi içinde idari yargıda iptal davası açabilecektir.

\section{KAYNAKÇA}

AKTEKİN Uğur/GÜRBÜZ Bahar, “Türkiye’de Örtülü Reklamlar ve Uygulamadaki Durum”, Ankara Barosu Fikri Mülkiyet ve Rekabet Hukuku Dergisi, C. 9, S. 4, 2009, s. 41-55.

AKYILMAZ Bahtiyar/SEZGİNER Murat/KAYA Cemil, Türk İdare Hukuku, 10. Baskı, Savaş Yayınevi, Ankara, 2019.

ALTUN Abdurrahim, Türk Borçlar Hukukunda Reklam Yapım Sözleşmesi, Adalet Yayınevi, Ankara, Ocak 2020.

AYAYDIN Dilhun, Radyo ve Televizyon Üst Kurulu’nun Kamu Yayıncılığı ve Özel Yayıncllık Üzerindeki Yetkileri (Yayımlanmamış Doktora Tezi), Ankara Üniversitesi, Sosyal Bilimler Enstitüsü, Ankara, 2014.

BALASUBRAMANIAN Siva K., "Beyond Advertising and Publicity: Hybrid Messages and Public Policy Issues", Journal of Advertising, C. 23 S. 4, 1994, s. 29-46.

ÇATALOĞLU Burcu Bahar, "Reklama Hukuki Açıdan Bir Bakış", Yıldırım Beyazıt Hukuk Dergisi, C. 5, S. 2, 2020, s. 599-632.

ER Eda, "Reklam ve Sinema: Sinema Filmlerinde Ürün Yerleştirme”, Yeni Düşünceler, S. 7, 2013, s. 145-159. 
GÖZLER Kemal/KAPLAN Gürsel, İdare Hukuku Dersleri, 22. Baskı, Ekin Kitabevi, Bursa, 2020.

GUPTA Pola B./BALASUBRAMANIAN Siva K./KLASSEN Michael L., "Viewers' Evaluations of Product Placements in Movies: Public Policy Issues and Managerial Implications", Journal of Current Issues \& Research in Advertising, C. 22, S. 2, 2000, s. 41-52,

GUPTA Pola B./LORD Kenneth R., "Product Placement in Movies: The Effect of Prominence and Mode on Audience Recall”, Journal of Current Issues \& Research in Advertising, C. 20, S. 1, 1998, s. 47-59.

GÜLAN Aydın, “Kamu Hizmeti Kavramı”, İdare Hukuku ve İlimleri Dergisi, C. 9, S. 1-3, 1988, s. 147-159.

ICC, ICC Advertising and Marketing Communications Code, 2018 Edition, https://iccwbo.org/content/ uploads/sites/3/2018/09/icc-advertising-and-marketing-communications-code-int.pdf, Erişim Tarihi: 14.03.2020.

İSBİR Begüm, “Kamu Hizmeti İlkeleri Işı̆̆ında Özel Radyo-Televizyon Yayıncılığının Değerlendirilmesi”, Gazi Üniversitesi Hukuk Fakültesi Dergisi, C. 21, S. 1-2, 2007, s. 815-835.

KOÇAK Elif, ““Ürün yerleştirme”ye ilgi artıyor”, T. 08.05.2012, Anadolu Ajansı, https://www.aa.com.tr/tr/ yasam/urun-yerlestirmeye-ilgi-artiyor/369518, Erişim Tarihi: 17.03.2021.

MAZICI Emel Tanyeri/ATEŞ Nur Banu/YILDIRIM Ayşe, “Televizyon Programlarında Ürün Yerleştirme: "Survivor All Star” Örneği”, Selçuk İletişim, C. 9, S. 4, 2017, s. 238-257.

ÖZAY İl Han, Günışı̆̆ında Yönetim, 3. Baskı, Filiz Kitabevi, İstanbul, 2017.

ÖZTÜRK Selen/OKUMUŞ Abdullah, "Pazarlama İletişimi Aracı Olarak Ürün Yerleştirme: Kavramsal Bir Çerçeve”, İstanbul Üniversitesi İşletme Fakültesi İşletme İktisadı Enstitüsü Yönetim Dergisi, C. 25, S. 76, 2014, s. 1-34.

Sağlık Bakanlığı, Çocuklara Yönelik Aşırı Tüketimi Tavsiye Edilmeyen Gıdalar ve İçecekler İle İlgili Reklamlar İçin Besin Profili Modeli Kullanım Rehberi, https:/hsgm.saglik.gov.tr/depo/birimler/saglikli-beslenmehareketli-hayat-db/tuz-ve-saglik/Besin_Profili_Modeli_Kullanim_Rehberi_1.6.2018.pdf, Erişim Tarihi: 27.03.2021.

SERTER Yusuf Sertaç, Kamu Hizmeti Kavramının Ekonomik Nedenlerle Geçirdiği Dönüşüm Bağlamında Virtüel Kamu Hizmeti ve Evrensel Hizmet Kurumları Üzerine Bir Karşılaştırma, Adalet Yayınevi, Ankara, 2019.

SNYDER Steven L, "Movies and Product Placement: Is Hollywood Turning Films into Commercial Speech", University of Illinois Law Review, C. 1992, S. 1, 1992, s. 301-338.

SÜRÜCÜ Pelin, "Marka Yerleştirmenin Bir Reklam Olarak Etkileri: Video Oyunlarındaki Marka Yerleştirme Uygulamaları Üzerine Keşifsel Bir Araştırma”, Hacettepe Üniversitesi İktisadi ve İdari Bilimler Fakültesi Dergisi, C. 25, S. 2, 2007, s. 169-188.

SYDOW Lexi, "The Impact of Coronavirus on the Mobile Economy", https://www.appannie.com/en/insights/ market-data/coronavirus-impact-mobile-economy/, Erişim Tarihi: 12.03.2021.

ŞEN Ersan, "Radyo ve Televizyonların Yayın İçeriklerinden Sorumluluğu”, 01.01.2021, https://sen.av.tr/tr/ makale/radyo-ve-televizyonlar\%C4\%B1n-yay\%C4\%B1n-iceriklerinden-sorumlulugu, Erişim Tarihi: 17.03.2021.

TANSEL İLİC Deniz, “Türkiyedeki Anaakım Televizyon Kanallarında Editoryal Bağımsızlık -Profesyonellik İdeolojisi İlişkisi”, Gümüşhane Üniversitesi İletişim Fakültesi Elektronik Dergisi, C. 2, S. 4, 2014, s. 100 122.

TIĞLI Mehmet, “Bir Aktör Olarak Markalar: Ürün Yerleştirme”, Türkmen Kitabevi, İstanbul, 2004.

TÜZÜN ATEŞALP Selin/TAŞDEMİR Babacan, “Ürün Yerleştirme ve Editoryal İçerik ile İlgili Artan Kaygılar: Türkiye'de Televizyon Draması Sektörü Örneği”, Galatasaray Üniversitesi İletişim Dergisi, S. 21, 2014, s. 51-78. 
YAŞAR Nuri, “Kamu Hizmeti, Virtüel Kamu Hizmeti ve 1999 Anayasa Değişikliği”, İdare Hukuku ve İlimleri Dergisi, C. 14, S. 1, 2000, s. 442-452.

YAZICI Fikret, "Ürün Yerleştirme Uygulamasının Hukuki Boyutu: ABD, Avrupa Ülkeleri ve Türkiye Üzerine Bir Değerlendirme”, Erciyes Üniversitesi Sosyal Bilimler Enstitüsü Dergisi, C. 30, S. 40, 2016, s. 93-119.

YILDIRIM Erhan/CAN Aytekin, "Reklamcılığın Farklı Bir Yüzü Olan Ürün Yerleştirmenin Televizyon Dizilerinde Kullanımı ve And Pastel İnşaatın 'İstanbul'lu Gelin’ Dizisi İçerisinde Ürün Yerleştirme Uygulamasının Çözümlemesi”, Selçuk İletişim, C. 12, S. 2, 2019, s. 680-707.

YOLCU Tarık, Pazarlama İletişim Aracı Olarak Film ve Dizilerde Ürün Yerleştirme, İKSAD Yayınevi, Ankara, 2020.

YURDİGÜL Yusuf/YÜKSEL Hakan, “TV Haberciliğinde Editoryal Bağımsızlık Sorunu: Türkiye Televizyon Haberciliğinde Editoryal Bağımsızlık Sorununa İlişkin Alan Araştırması”, Selçuk İletişim, C. 7, S. 4, 2013, s. 140-151.

ZEREN Deniz/PAYLAR Önder Ziya, Ürün Yerleştirme, Karahan Kitabevi, Adana, Kasım 2014.

http://www.ssuk.org.tr/eski_site_verileri/kurul/115.doc, Erişim Tarihi: 23.03.2021.

https://eur-lex.europa.eu/legal-content/EN/TXT/?uri=CELEX\%3A02010L0013.201.81218\#B-16, Erişim Tarihi: 14.03.2021.

https://www.ticaret.gov.tr/tuketici/ticari-reklamlar/reklam-kurulu-kararlari, Erişim Tarihi: 15.03.2021.

https://legalbank.net

www.rtuk.gov.tr 